\title{
Knots Untie: Molecular Determinants Involved in Knot Formation Induced by Pseudomonas savastanoi in Woody Hosts
}

\author{
Eloy Caballo-Ponce ${ }^{1}$, Jesús Murillo², Marta Martínez-Gil' ${ }^{1}$, Alba Moreno-Pérez', \\ Adrián Pintado ${ }^{1}$ and Cayo Ramos ${ }^{1 *}$
}

'Área de Genética, Facultad de Ciencias, Instituto de Hortofruticultura Subtropical y Mediterránea 'La Mayora', Universidad de Málaga-Consejo Superior de Investigaciones Científicas, Málaga, Spain, ${ }^{2}$ Departamento de Producción Agraria, ETS de Ingenieros Agrónomos, Universidad Pública de Navarra, Pamplona, Spain

\section{OPEN ACCESS}

Edited by:

Carolina Escobar.

Universidad de Castilla-La Mancha,

Spain

Reviewed by:

David Baltrus,

University of Arizona, United States Murray Grant,

University of Warwick,

United Kingdom

*Correspondence: Cayo Ramos crr@uma.es

Specialty section:

This article was submitted to Plant Microbe Interactions,

a section of the journal

Frontiers in Plant Science

Received: 31 March 2017 Accepted: 06 June 2017

Published: 21 June 2017

Citation:

Caballo-Ponce E, Murillo J, Martínez-Gil M, Moreno-Pérez A,

Pintado A and Ramos C (2017) Knots Untie: Molecular Determinants Involved in Knot Formation Induced by Pseudomonas savastanoi in Woody Hosts.

Front. Plant Sci. 8:1089. doi: 10.3389/fpls.2017.01089
The study of the molecular basis of tree diseases is lately receiving a renewed attention, especially with the emerging perception that pathogens require specific pathogenicity and virulence factors to successfully colonize woody hosts. Pathosystems involving woody plants are notoriously difficult to study, although the use of model bacterial strains together with genetically homogeneous micropropagated plant material is providing a significant impetus to our understanding of the molecular determinants leading to disease. The gammaproteobacterium Pseudomonas savastanoi belongs to the intensively studied Pseudomonas syringae complex, and includes three pathogenic lineages causing tumorous overgrowths (knots) in diverse economically relevant trees and shrubs. As it occurs with many other bacteria, pathogenicity of $P$. savastanoi is dependent on a type III secretion system, which is accompanied by a core set of at least 20 effector genes shared among strains isolated from olive, oleander, and ash. The induction of knots of wild-type size requires that the pathogen maintains adequate levels of diverse metabolites, including the phytohormones indole-3-acetic acid and cytokinins, as well as cyclic-di-GMP, some of which can also regulate the expression of other pathogenicity and virulence genes and participate in bacterial competitiveness. In a remarkable example of social networking, quorum sensing molecules allow for the communication among $P$. savastanoi and other members of the knot microbiome, while at the same time are essential for tumor formation. Additionally, a distinguishing feature of bacteria from the $P$. syringae complex isolated from woody organs is the possession of a $15 \mathrm{~kb}$ genomic island (WHOP) carrying four operons and three other genes involved in degradation of phenolic compounds. Two of these operons mediate the catabolism of anthranilate and catechol and, together with another operon, are required for the induction of full-size tumors in woody hosts, but not in non-woody micropropagated plants. The use of transposon mutagenesis also uncovered a treasure trove of additional $P$. savastanoi genes affecting virulence and participating in diverse bacterial processes. Although there is still much to be learned on what makes a bacterium a successful pathogen of trees, we are already untying the knots.

Keywords: bacterial gall, olive knot, woody host, Pseudomonas savastanoi, Pseudomonas syringae, IAA, cytokinins, T3SS 


\section{KNOT, KNOT, WHO'S THERE?}

Bacterial galls are characterized by tumorous overgrowths, also known as knots, produced on the stems, leaves, and roots of plants infected with certain bacterial phytopathogens and constitute an important group of plant diseases that cause serious reductions in crop yields and considerable economic losses (Agrios, 2005). Records of bacterial galls go back many centuries; Theophrastus' description of the formation of knots on the trunks and branches of olive trees in the fourth century B.C. is likely one of the first clear descriptions of plant diseases (Iacobellis, 2001). In contrast, the causal relationship between bacteria and plant galls was not clearly established until the end of the nineteenth century by the Italian plant pathologists Luigi Savastano and Fridiano Cavara; they determined the bacterial etiology of olive knot disease (Pseudomonas savastanoi pv. savastanoi) (Pierce, 1891) and crown gall of grape (Agrobacterium tumefaciens) (Cavara, 1897). From then, several bacterial species and genera have been demonstrated to cause galls on plants.

Agrobacterium tumefaciens and related species, the only gallinducing bacterial species that transfer and integrate a fragment of its own DNA (i.e., the T-DNA), into the plant genome (Chilton et al., 1977), cause galls at the base of the trunk and roots on a wide range of woody plant species (Gelvin, 2003). Over 90 families of plants have been found to be susceptible to crown gall disease. However, the bacteria are primarily found in nature on woody plants, such as stone fruits, pome fruits, willows, and grapes (Gelvin, 2003; Pulawska, 2010). Due to their unique mode of action, these species of bacteria have been converted into both a relevant model for the study of plant-bacteria interactions and a biotechnological tool for plant breeding and transformation.

Carrot bacterial gall, first tentatively attributed to A. tumefaciens or to the root knot nematode Meloidogyne spp., is caused by distinctive Gram-negative bacteria, Rhizobacter dauci, which were not recorded in plant bacteriology until the end of the 1980s. Infected plants develop galls along the entire length of the storage roots from the crown to the root tip (Goto and Kuwata, 1988). R. dauci appears to have an extremely wide host range and produces galls on the roots, stems and tubers of at least 46 plant species from 24 families, including relevant vegetables such as tomato and cabbage as well as many common weeds (Kawarazaki et al., 2009, 2012).

Pantoea agglomerans, a species of commensal bacteria associated with many plant species, has evolved into a host-specific gall-forming pathogen by acquiring a plasmidborne pathogenicity island. The best-known strains belong to $P$. agglomerans pathovars betae and gypsophilae. While $P$. agglomerans pv. betae elicits gall formation in both gypsophila (Gypsophila paniculata L) and beet (Beta vulgaris L.), P. agglomerans pv. gypsophilae induces symptoms only in gypsophila (Barash and Manulis-Sasson, 2007). Interestingly, $P$. agglomerans strains inhabiting olive trees as harmless endophytes have been shown to cooperate with strains of $P$. savastanoi, forming a stable bacterial consortium that increases the severity of olive knot disease (Hosni et al., 2011).

Rhodococcus fascians, an actinomycete that induces the formation of tissue hyperplasia (i.e., leafy gall syndrome), is the only described species of Gram-positive $(+)$ bacteria that causes plant galls. $R$. fascians infects a wide range of plants, primarily dicotyledonous herbs; it initiates the formation of leafy galls consisting of amplified shoot centers and inhibits shoot growth. Because of similarities in disease symptoms and the host range, it was hypothesized that $R$. fascians might be the Gram-positive counterpart of A. tumefaciens. However, transfer of bacterial DNA to the plant genome could not be demonstrated for this bacterium (Goethals et al., 2001).

Although diverse gall-forming bacteria exhibit common features during infection and symptom development, such as the production of phytohormones, different bacteria use distinctive systems to produce galls. In this review, we focus on the molecular mechanisms involved in tumor formation by a model bacterial pathogen of woody hosts, P. savastanoi.

\section{TUMORIGENIC PATHOVARS OF $P$ savastanoi}

The species $P$. savastanoi is a member of the Pseudomonas syringae complex and includes four pathovars causing knots or excrescences in woody hosts. These are $P$. savastanoi pv. savastanoi (Psv), pv. nerii (Psn), pv. fraxini (Psf) and pv. retacarpa (Psr), comprising isolates from olive (Olea europaea), oleander (Nerium oleander), ash (Fraxinus excelsior) and Spanish broom (Retama sphaerocarpa), respectively (Gardan et al., 1992a; Bull et al., 2010) (Table 1). Additionally, DNA-DNA hybridization studies formally classified the causative agents of bacterial brown spot of soybeans and halo blight disease of beans into the species P. savastanoi (i.e., P. savastano $i$ pv. glycinea and $P$. savastano pv. phaseolicola, respectively) (Gardan et al., 1992a). However, it is now clear that $P$. savastanoi belongs to a larger phylogenetic group, which should be called $P$. amygdali when elevated to the species rank, comprising 25 pathovars and four additional Pseudomonas species, and that pathovars Psv, Psn, Psf, and Psr are phylogenetically closer to other pathovars infecting trees than to pv. glycinea and pv. phaseolicola (Gardan et al., 1999; Nowell et al., 2014; Baltrus et al., 2017). Remarkably, this phylogenetic group, also known as genomospecies 2 (Gardan et al., 1999) and phylogroup 3 (Baltrus et al., 2017), is the only one from the $P$. syringae complex containing bacteria causing tumors in woody hosts, namely Psv, Psn, Psr, P. meliae, P. tremae and P. syringae pathovars cerasicola, daphniphylli, dendropanacis, myricae, and rhaphiolepidis (Lamichhane et al., 2014).

While artificial infections with Psv, Psn, and Psr strains cause knots, Psf isolates induce cankers accompanied by wart-like excrescences in both ash and olive. Psv strains induce knot formation in olive and ash but not in oleander, whereas Psn strains can infect all three hosts. In contrast, the host range of Psr isolates is restricted to Spanish broom (Janse, 1982; Iacobellis et al., 1998; Ramos et al., 2012). Knot formation by $P$. savastanoi has also been described in several other hosts, including jasmine (Gardan et al., 1992b), privet (Gardan et al., 1992b), mock privet (Gardan et al., 1992b), forsythia (Bradbury, 1986), buckthorn (Temsah et al., 2007a), fontanesia (Mirik et al., 2011), pomegranate (Bozkurt et al., 2014), myrtle (Goumas et al., 
TABLE 1 | Pathovar assignation of $P$. savastanoi strains isolated from diverse woody hosts.

\begin{tabular}{|c|c|c|c|c|}
\hline Host family & Host genera/species & Common name & Pathovar ${ }^{a}$ & Reference \\
\hline Apocynaceae & Nerium oleander & Oleander & nerii & Janse, 1982 \\
\hline Lythraceae & Punica granatum & Pomegranate & savastanoib & Bozkurt et al., 2014 \\
\hline Myrtaceae & Myrtus communis & Myrtle & NA & Temsah et al., 2007b \\
\hline \multirow[t]{7}{*}{ Oleaceae } & Fontanesia phillyreoides & Fontanesia & savastanoib & Mirik et al., 2011 \\
\hline & Fraxinus excelsior & Ash & fraxini & Janse, 1982 \\
\hline & Jasminum spp. & Jasmine & NA & Gardan et al., 1992b \\
\hline & Ligustrum spp. & Privet & NA & Gardan et al., 1992b \\
\hline & Olea europaea & Olive & savastanoi & Janse, 1982 \\
\hline & Osmanthus fragrans & Sweet olive & NA & Cinelli et al., 2013 \\
\hline & Phillyrea spp. & Mock privet & NA & Gardan et al., 1992b \\
\hline
\end{tabular}

aNA, not assigned.

${ }^{\mathrm{b}}$ For fontanesia and pomegranate isolates, the assignation to pv. savastanoi was based in biochemical tests, fatty acid profiling, and PCR.

2000; Temsah et al., 2007b; Cinelli et al., 2014) and dipladenia (Putnam et al., 2010; Eltlbany et al., 2012; Pirc et al., 2014; Caballo-Ponce and Ramos, 2016) (Table 1). Although these P. savastanoi hosts are classified in several plant families, over $50 \%$ of them belong to the Oleaceae family. Lack of accurate cross-pathogenicity tests for most of these strains preclude their classification within any of the four well-established P. savastanoi pathovars causing diseases in woody hosts (Table 1).

Knot induction by $P$. savastanoi in woody hosts is characterized by the formation of hypertrophic and hyperplastic overgrowths on the trunks, stems and branches; however, this symptomatology is rarely observed on the leaves and fruits (Janse, 1980; Rodríguez-Moreno et al., 2008, 2009; Mirik et al., 2011; Eltlbany et al., 2012; Ramos et al., 2012; Bozkurt et al., 2014). Considerable progress in identifying and understanding bacterial mechanisms that govern knot generation by $P$. savastanoi, some of which are specific to woody host pathogens, has been achieved in recent years (Table 2) and will be reviewed below.

\section{P. savastanoi-INDUCED KNOTS: A MODIFIED TISSUE STRUCTURE CONNECTED WITH THE STEM VASCULAR SYSTEM}

The life cycle of $P$. savastanoi has been most extensively characterized for olive isolates. Psv lives epiphytically on the surface of leaves and stems and reaches the highest cell populations in warm, rainy months (Ercolani, 1978; Quesada et al., 2007). However, these bacteria are able to switch from an epiphytic to an endopathogenic lifestyle after penetration into plant tissues through wounds generated by climatic conditions or agricultural practices. As a pathogen, P. savastanoi induces hypertrophy and hyperplasia of plant tissues, generally leading to the generation of knots (Figures 1A,B), an exception occurs in ash infections by Psf strains, which induce the formation of small protuberances (i.e., cankers or excrescences) (Figure 1C).
A histological examination of the knots induced by P. savastanoi infections in different hosts reveals strong similarities among olive (Surico, 1977; Temsah et al., 2008; Rodríguez-Moreno et al., 2009), oleander (Wilson, 1965; Temsah et al., 2010), buckthorn (Temsah et al., 2007a), and myrtle (Temsah et al., 2007b). During the early stages of an infection, bacteria are localized in the intercellular spaces of the cortical parenchyma and in the vascular tissues damaged by the wound, where bacterial pectolytic and hemicellulolytic enzymatic activities cause cell wall degradation of adjacent plant cells, resulting in the plasmolysis of host cells and the generation of internal cavities. Bacterial cells colonize these cavities and multiply, while lignin deposits appear as a defense mechanism in the cell walls of plasmolyzed cells. Adjacent to them, the parenchymal cells of the cortex and vascular system show hypertrophic and hyperplastic activities initiated by coenocytic divisions, resulting in multinucleated cells. Additionally, in oleander infections, tyloses develop in the xylem vessels, hampering bacterial movement (Temsah et al., 2010).

Subsequent enlargement of the internal cavities and hyperplastic tissues result in the formation of an incipient multilobed knot. Additionally, the parenchyma cells adjacent to the bacterial cavities have been shown to differentiate into xylem elements (Figure 1D), which are connected with the primary vascular cylinder in olive infections (Rodríguez-Moreno et al., 2009). Taking into account that neovascularization is essential for the growth of plant and animal tumors (Ullrich and Aloni, 2000), the existence of this network of vascular tissues might facilitate the supply of water and nutrients necessary for the knots to reach their final size. The existence of a vascular connection between plant galls and the vascular system of the host plant has also been reported in A. tumefaciens-induced crown galls (Aloni et al., 1995).

During later stages of knot development, the hypertrophied tissue is composed of groups of disorganized cells, except for those being part of the xylem vessels generated during the infection. Psv cells have been visualized inside olive knots 
TABLE 2 | Described mutations affecting virulence and pathogenicity factors in tumorigenic pathovars of Pseudomonas savastanoi.

\begin{tabular}{|c|c|c|c|c|c|c|}
\hline Trait affected & Gene & Pathovar & Function & $\begin{array}{l}\text { Effect in knot } \\
\text { development }\end{array}$ & Other phenotypes & Reference \\
\hline \multirow[t]{5}{*}{ Metabolism of IAA } & $p-\mid A A^{a}$ & savastanoi/nerii & IAA biosynthesis & Absence of knot & Enhanced swarming & $\begin{array}{l}\text { Comai and Kosuge, } \\
\text { 1980; Surico et al., } \\
\text { 1985; Soby et al., } 1991\end{array}$ \\
\hline & iaaM $H^{\mathrm{b}}$ & savastanoi & IAA biosynthesis & Absence of knot & & Aragón et al., 2014 \\
\hline & iaaM & nerii & IAA biosynthesis & Absence of knot & & $\begin{array}{l}\text { Cerboneschi et al., } \\
2016\end{array}$ \\
\hline & iaaL & nerii & IAA conjugation & Volume reduction & & $\begin{array}{l}\text { Glass and Kosuge, } \\
1988\end{array}$ \\
\hline & iaaL & nerii & IAA conjugation & Volume increase & & $\begin{array}{l}\text { Cerboneschi et al., } \\
2016\end{array}$ \\
\hline \multirow[t]{2}{*}{ Production of cytokinins } & $\Delta \mathrm{p}-p t z^{\mathrm{C}}$ & nerii & $\begin{array}{l}\text { Cytokinin } \\
\text { biosynthesis }\end{array}$ & Volume reduction & & lacobellis et al., 1994 \\
\hline & $\Delta \mathrm{pPsv} 48 \mathrm{~A}^{\mathrm{c}}$ & savastanoi & $\begin{array}{l}\text { Cytokinin } \\
\text { biosynthesis }\end{array}$ & Volume reduction & & Bardaji et al., 2011 \\
\hline \multirow[t]{6}{*}{ Type III secretion system } & hrcC & savastanoi & $\begin{array}{l}\text { Outer membrane } \\
\text { pore protein }\end{array}$ & Absence of knot & $\begin{array}{l}\text { No HR }{ }^{d} \text { in Nicotiana } \\
\text { tabacum }\end{array}$ & Sisto et al., 2004 \\
\hline & hrpA & savastanoi & Pilin protein & Absence of knot & $\begin{array}{l}\text { Unable to multiply in } \\
\text { plant tissue No } \mathrm{HR}^{\mathrm{d}} \text { in } \\
\text { Nicotiana tabacum }\end{array}$ & $\begin{array}{l}\text { Pérez-Martínez et al., } \\
2010\end{array}$ \\
\hline & & nerii & Pilin protein & Absence of knot & & $\begin{array}{l}\text { Cerboneschi et al., } \\
2016\end{array}$ \\
\hline & hrpR & savastanoi & $\begin{array}{l}\text { Transcriptional } \\
\text { regulator }\end{array}$ & Absence of knot & $\begin{array}{l}\text { Unable to multiply in } \\
\text { plant tissue }\end{array}$ & Matas et al., 2012 \\
\hline & hrpL & savastanoi & $\begin{array}{l}\text { Transcriptional } \\
\text { regulator (sigma-54) }\end{array}$ & Absence of knot & $\begin{array}{l}\text { No } \mathrm{HR}^{\mathrm{d}} \text { in Nicotiana } \\
\text { tabacum }\end{array}$ & Matas et al., 2014 \\
\hline & hорAO1 & savastanoi & Phosphatase & $\begin{array}{l}\text { Volume reduction } \\
\text { Increased necrosis }\end{array}$ & $\begin{array}{l}\text { Reduced } \\
\text { competitiveness in olive } \\
\text { plants }\end{array}$ & $\begin{array}{l}\text { Castañeda-Ojeda et al. } \\
2017 b\end{array}$ \\
\hline \multirow[t]{3}{*}{ c-di-GMP metabolism } & bifA & savastanoi & Phosphodiesterase & Volume reduction & Reduced swimming & Aragón et al., 2015a \\
\hline & $d g c P$ & savastanoi & Diguanylate cyclase & Volume reduction & $\begin{array}{l}\text { Increased swimming } \\
\text { Reduced biofilm } \\
\text { formation Decreased } \\
\text { expression of T6SS } \\
\text { genes (hcp1 and vgrG) }\end{array}$ & Aragón et al., 2015b \\
\hline & ple $D^{\mathrm{e}}$ & savastanoi & Diguanylate cyclase & $\begin{array}{l}\text { Volume increase } \\
\text { Reduction of necrotic } \\
\text { tissue }\end{array}$ & $\begin{array}{l}\text { Reduced swimming } \\
\text { Increased biofilm } \\
\text { formation }\end{array}$ & $\begin{array}{l}\text { Perez-Mendoza et al., } \\
2014\end{array}$ \\
\hline \multirow[t]{2}{*}{ Quorum sensing } & $|u x|$ & savastanoi & AHL synthase & Volume reduction & $\begin{array}{l}\text { Reduced } \\
\text { exopolysaccharide } \\
\text { production }\end{array}$ & Hosni et al., 2011 \\
\hline & $\operatorname{lu} \times R$ & savastanoi & AHL receptor & Volume reduction & $\begin{array}{l}\text { Reduced } \\
\text { exopolysaccharide } \\
\text { production }\end{array}$ & Hosni et al., 2011 \\
\hline \multirow[t]{3}{*}{ Metabolism of phenolics } & antA & savastanoi & $\begin{array}{l}\text { Anthranilate } \\
\text { catabolism }\end{array}$ & Volume reduction & & $\begin{array}{l}\text { Caballo-Ponce et al., } \\
2017\end{array}$ \\
\hline & catB & savastanoi & Catechol catabolism & Volume reduction & & $\begin{array}{l}\text { Caballo-Ponce et al., } \\
2017\end{array}$ \\
\hline & $i p o A B C^{b}$ & savastanoi & $\begin{array}{l}\text { Oxygenase on } \\
\text { phenolics }\end{array}$ & Volume reduction & & $\begin{array}{l}\text { Caballo-Ponce et al., } \\
2017\end{array}$ \\
\hline
\end{tabular}

analyzed in strains cured of a plasmid encoding the iaaMH operon.

${ }^{\mathrm{b}}$ Genes iaaM-iaaH and ipoA-ipoB-ipoC are organized in operons.

${ }^{\mathrm{C}}$ Analyzed in strains cured of a plasmid encoding the ptz gene.

d HR, hypersensitive response.

e Overexpression of pleD from Caulobacter crescentus.

forming small groups and microcolonies, which remain attached to the surface of hypertrophied host cells and to each other by an extracellular matrix. However, most bacterial cells are found forming multilayer biofilms localized within the internal cavities of the neoplastic tissue (Figure 1E), and surrounding the stem vascular system. In olive knots, Psv cells have also 

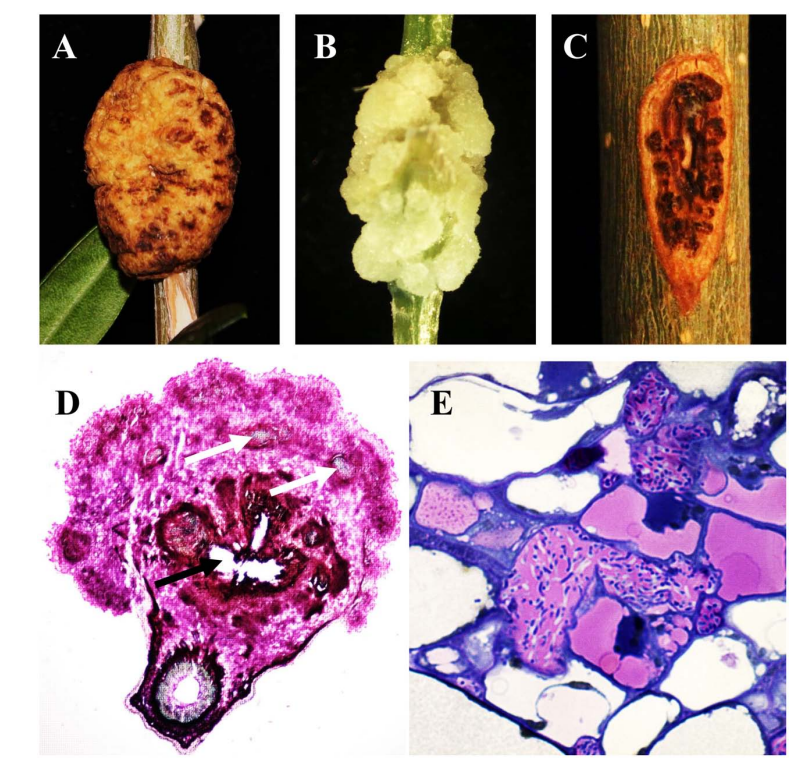

FIGURE 1 | Symptoms induced by Pseudomonas savastanoi and pathogen visualization within knots. Knots induced by Psv NCPPB 3335 in (A) woody olive trees at 90 days post-inoculation (dpi) and (B) micropropagated (non-woody) olive plants at 28 dpi. (C) Excrescence-like symptoms generated by Psf NCPPB 1006 at 90 dpi in ash. (D) Transverse section of a 30-dpi olive knot stained with xylene blue-pyrofuchsin. White and black arrows indicate newly formed xylem vessels and cavities within the knot, respectively.

(E) Detail of bacterial cavity within a 35-dpi olive knot filled with Psv cells.

been visualized in the lumen of newly formed xylem vessels, suggesting that the pathogen might migrate through the vascular system (Rodríguez-Moreno et al., 2009; Maldonado-González et al., 2013). In oleander infections, Psn cells have been visualized in xylem vessels and also in laticifers, where they multiply and spread systemically (Wilson and Magie, 1964). In addition, the pressure generated by continuous hyperplastic activity causes the appearance of fissures in the knot tissues. The enlargement of these fissures produces breakage of the periderm and exposure of the internal cavities filled with bacteria to the environment, which contributes to pathogen spread.

\section{PATHOGEN-PRODUCED PHYTOHORMONES AND THEIR ROLE IN DISEASE}

Phytohormones have a central role in plant defenses against abiotic and biotic stresses such as drought, herbivores and pathogens (O’Brien and Benková, 2013; Ma and Ma, 2016). It is thus not surprising that many types of pathogens evolved diverse strategies to interfere with the biosynthesis or activity of phytohormones, both to dampen plant immunity and to obtain shelter and nutrients (Boivin et al., 2016; Ma and Ma, 2016). However, it is their balance that ultimately modulates plant responses; thus, many non-pathogenic bacteria also synthesize phytohormones, which contributes to enhanced plant growth and health (Arkhipova et al., 2007; Kudoyarova et al., 2014).

\section{Indole-3-Acetic Acid, a P. savastanoi Pathogenicity Determinant for Knot Formation}

The auxin phytohormone indole-3-acetic acid (IAA) is required for growth and development of plant tissues (Santner and Estelle, 2009; Kieffer et al., 2010). However, bacterial production of IAA can interfere with plant development by disturbing the auxin balance in plants (Spaepen and Vanderleyden, 2011). Furthermore, biosynthesis of IAA has been described as a pathogenicity or virulence factor in bacterial phytopathogens (Patten et al., 2013). Redundancy in IAA biosynthesis is widespread among plant-associated bacteria, and several IAA biosynthetic pathways have been described, most of which are dependent on L-tryptophan as a precursor (Spaepen et al., 2007). Production of IAA by phytopathogenic bacteria via the indole-3-acetamide pathway was first characterized in the gallforming pathogens A. tumefaciens and P. savastanoi (Smidt and Kosuge, 1978; Thomashow et al., 1984). In P. savastanoi, tryptophan is initially converted into indole-3-acetamide by tryptophan 2-monooxygenase (encoded by the iaaM gene) and later transformed into the final product, IAA, in a reaction catalyzed by indole-3-acetamide hydrolase (encoded by the iaaH gene) (Magie et al., 1963; Kosuge et al., 1966). Organization of the iaaM and iaaH genes as an operon (iaaMH) has been described in several P. savastanoi strains (Comai and Kosuge, 1980; Palm et al., 1989; Comai et al., 1992). However, while most Psv strains encode the $i a a M H$ operon on the chromosome, Psn isolates usually harbor these genes on plasmids (Glass and Kosuge, 1986; Caponero et al., 1995; Pérez-Martínez et al., 2008). In addition, subsequent analyses have revealed that Psv strains frequently encode two copies of the iaaMH operon (named iaaMH1 and iaaMH2), both of which are located on the chromosome (PérezMartínez et al., 2008; Rodríguez-Palenzuela et al., 2010). In the model Psv strain NCPPB 3335, the iaaM2 gene encodes an internal insertion of 22 nucleotides. In addition, a knock-out iaaMH2 mutant of this strain produces similar amounts of IAA as the wild-type strain, suggesting that this extra copy of the operon is not functional (Aragón et al., 2014). Interestingly, single- (iaaMH1) and double- (iaaMH1 and iaaMH2) deletion mutants of Psv NCPPB 3335 produce residual amounts of IAA, suggesting that redundancy in the IAA biosynthetic pathways also occurs in P. savastanoi (Aragón et al., 2014).

The role of IAA production in the pathogenicity of Psv and Psn isolates has been examined using different approaches. First, Psv and Psn strains resistant to the growth inhibitor $\alpha$-methyltryptophan and showing an altered production of IAA were isolated. While Psv and Psn IAA-deficient mutants failed to cause knot development in olive and oleander plants, respectively, Psn strains overproducing this phytohormone formed larger knots than the wild-type strain (Smidt and Kosuge, 1978; Surico et al., 1985), thus suggesting the role of this phytohormone in the pathogenicity of $P$. savastanoi. A different tryptophan analog, 5-methyltryptophan, has been 


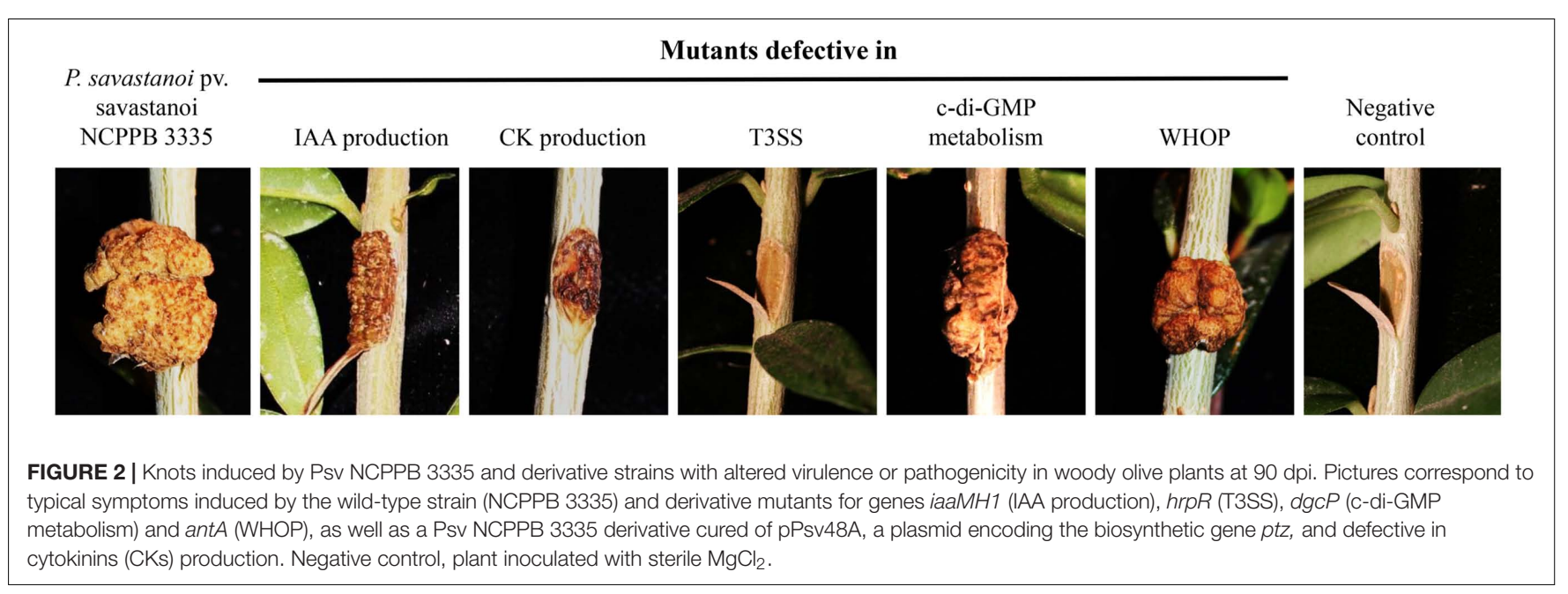

used for the isolation of $P$. savastanoi strains cured of iaaMencoding plasmids. This strategy is based on the toxicity of 5methyltryptophan for $P$. savastanoi mutants lacking tryptophan 2-monooxygenase activity (i.e., iaaM gene). Thus, $P$. savastano $i$ mutants sensitive to 5-methyltryptophan and lacking the iaaM gene were selected upon treatment of bacterial cells with the DNA-intercalating agent acridine orange (Comai and Kosuge, 1980). Although Psn cells without iaaM-encoding plasmids were able to induce necrosis in the tissues into which they were inoculated, they failed to generate knots in oleander plants (Iacobellis et al., 1994). Construction of the single iaaMH1 and the double iaaMH1 iaaMH2 mutants mentioned above in Psv NCPPB 3335 provided direct evidences for the involvement of this operon in Psv pathogenicity. As expected from their low IAA levels, knot induction by these two mutant strains was fully abolished, further supporting the role of IAA as a pathogenicity determinant in this bacterial pathogen (Aragón et al., 2014) (Figure 2).

In addition to IAA production, $P$. savastanoi might modulate the pool of free IAA by transforming it into a less biologically active amino acid conjugate, 3-indole-acetyl- $\varepsilon$-L-lysine (IAALys), through activity encoded in the iaaL gene (Hutzinger and Kosuge, 1968; Glass and Kosuge, 1986). The number of copies and the location of the iaaL gene differ among $P$. savastanoi pathovars. While Psv strains generally harbor two iaaL paralogs, both located in the chromosome, Psn strains usually encode the iaaL gene in plasmids (Matas et al., 2009). Furthermore, IAA-Lys has been detected in culture filtrates of Psn isolates, whereas this compound could not be detected in culture supernatants of Psv strains (Evidente et al., 1985). Bacteria from the $P$. syringae complex, including $P$. savastanoi, encode a putative multidrug and toxic compound extrusion transporter of the MATE family (matE gene) upstream of the iaaL gene. These genes have been shown to be transcribed either independently or as part of an operon in $P$. syringae pv. tomato DC3000. Interestingly, deletion of either of these two genes resulted in reduced fitness and virulence of DC3000 in tomato plants (Castillo-Lizardo et al., 2015). Nonetheless, the role of iaaL in the virulence of $P$. savastanoi seems to be dependent on the strain and the experimental conditions used. A Psn PB213 iaaL mutant obtained by Tn5 transposition displayed virulence attenuation in woody oleander plants in comparison with the wild-type strain (Glass and Kosuge, 1988). Conversely, a recent report showed that a knockout mutation of the iaaL gene in a different Psn isolate, Psn23, yielded a hypervirulent strain that resulted in a severe increase in knot size, higher systemic dispersion and a larger final population size than the wild-type strain in micropropagated (i.e., nonwoody) oleander plants (Cerboneschi et al., 2016). Further studies are necessary to clarify the role of the iaaL gene in the virulence of $P$. savastanoi strains isolated from different hosts.

\section{Production of Cytokinins by $P$. savastanoi Contributes to the Development of Mature Xylem Vessels within the Knots}

Cytokinins (CKs) are derivatives of adenine nucleotides with an isoprene-derived or aromatic side chain in position $N^{6}$ (Sakakibara, 2006); they have many diverse functions including control of various processes in plant growth and development and modulation of plant defenses against stresses (Sakakibara, 2006; O’Brien and Benková, 2013). P. savastanoi strains from olive and oleander produce at least zeatin, dihydrozeatin, 1'methyl-zeatin, ribosylzeatin, ribosyldihydrozeatin, and ribosyl1 "-methylzeatin, as well as diverse other methylated zeatin derivatives; however, the types and amounts of CKs types vary among strains (Surico et al., 1985; Evidente et al., 1986; MacDonald et al., 1986; Iacobellis et al., 1994).

The $p t z$ gene ( $\underline{P}$ seudomonas trans-zeatin producing gene, also called ipt; $705 \mathrm{nt}$ ), coding for an isopentenyl transferase (234 aa), is widely present in tumorigenic strains of P. savastanoi (Ramos et al., 2012). Thus, isolates of Psf inducing cankers, but not knots, on ash do not possess the ptz gene (Iacobellis et al., 1998). The deduced product of $p t z$ catalyzes the prenylation of adenosine 5'-phosphates (AMP, ADP, or ATP) with either dimethylallyl diphosphate or hydroxymethylbutenyl diphosphate, a main step in the isoprenoid CKs biosynthesis (Sakakibara, 2006). Although 
preceded by and in tight association with another gene, ptz appears to have its own promoter and, when expressed in E. coli, directs the biosynthesis of CKs (MacDonald et al., 1986; Powell and Morris, 1986), suggesting that it is the only specific gene from $P$. savastanoi responsible for CKs biosynthesis. The gene shows only approximately 50\% nucleotide identity with the homologous $t m r$ and $t z s$ genes from $A$. tumefaciens, with similar levels of identity among the corresponding products. The ptz gene is found in plasmid pPsv48A (PSPSV_A0024) of strain Psv NCPPB 3335 and in the chromosome or plasmids in other strains of Psv and Psn (Caponero et al., 1995; Pérez-Martínez et al., 2008; Ramos et al., 2012). Likewise, it is present in the draft genome of the tumorigenic Psr strain ICMP16945 (accession no. LJRD01000455).

The idi gene (previously called ipt; isopentenyl-diphosphate delta isomerase, 152 aa) is found in plasmid pPsv48C from Psv NCPPB 3335 and might also be involved in CKs biosynthesis. Its deduced product catalyzes the conversion of isopentenyl pyrophosphate to dimethylallyl diphosphate, which is a key step in biosynthesis of CKs through the mevalonate pathway (Sakakibara, 2006). However, homologs of this gene are present in a wide variety of bacteria, including E. coli, and it is possible that it carries functions other than or in addition to the biosynthesis of CKs.

The involvement of CKs in the pathogenicity and virulence of tumorigenic pseudomonads is supported by several lines of evidence. Early work already showed that the amount of IAA and CKs produced in culture by Psv and Psn strains was positively correlated with the production of larger knots even after the shortest incubation periods (Surico et al., 1985). Likewise, knots in olive plants caused by P. savastanoi strains without plasmids containing the ptz gene were smaller (Figure 2) and had fewer spiral vessels than knots induced by wild-type strains (Iacobellis et al., 1994; Rodríguez-Moreno et al., 2008; Bardaji et al., 2011). However, mutants that were unable to synthesize CKs reached similar populations sizes as the corresponding wild-type strains in oleander leaves (Iacobellis et al., 1994) and in olive tissues (Rodríguez-Moreno et al., 2008; Bardaji et al., 2011). Thus, CKs appear to be non-essential for tumor formation but to contribute to full expression of disease symptoms. Nevertheless, because previous assays were done with mutants obtained by plasmid curing, to precisely assess the contribution of CKs to the bacterial life cycle, it will be necessary to evaluate the behavior of genespecific mutants by themselves and in competition with wild-type strains.

\section{Phytohormone Crosstalk with Other Virulence Factors}

Regulatory networks involving crosstalk between phytohormones and other pathogenicity and virulence factors have been described in several plant pathogens, including the gall-forming bacterium $P$. agglomerans pv. gypsophilae (Chalupowicz et al., 2009). Biosynthesis of IAA in this pathogen takes place by two different pathways, the indole-3-acetamide and the indole-3-pyruvate routes, which differentially contribute to gall formation and epiphytic fitness, respectively (Manulis et al., 1998). While inactivation of the biosynthesis of either CKs or IAA through the indole-3-acetamide pathway led to repression of the type III secretion system (T3SS) and the quorum sensing system, transcriptional upregulation of these two systems was observed in a mutant unable to synthesize IAA via the indole-3-pyruvate pathway (Chalupowicz et al., 2009). Similarly, transcriptional downregulation of the T3SS, the global regulatory gene gacA and the pectate lyase genes pelD, pell, and pelL has been reported in a Dickeya dadantii (formerly known as Erwinia chrysanthemi) iaaM mutant (Yang et al., 2007).

Beyond the direct role of IAA in knot induction by $P$. savastanoi, only a few studies have suggested that this molecule might also function as a signaling molecule in this bacterium. Psn IAA-deficient mutants exhibit enhanced swarming motility (Table 2) (Soby et al., 1991), indicating that the internal IAA pool influences $P$. savastanoi motility. However, the expression of virulence-related genes in Psv mutants affected in the biosynthesis of CKs or IAA has not yet been analyzed. On the other hand, exogenous addition of IAA to a Psv NCPPB 3335 culture caused repression of the T3SS genes $h r p L$ and $h r p A$, whereas transcription of the type VI secretion system (T6SS) gene $\operatorname{vgrG}$ was activated (Aragón et al., 2014). These results, which are in accord with the repression of the vir regulon reported in $A$. tumefaciens cells exposed to exogenous IAA (Yuan et al., 2008), suggest an additional effect of IAA during the interaction of $P$. savastanoi with its hosts that deserves further exploration. Additionally, a ptz homolog gene and/or CKs appear to regulate the expression of diverse virulence genes in $A$. tumefaciens (Hwang et al., 2013). For this reason and because there is evidence that a plethora of beneficial and pathogenic microorganisms modulate the phytohormone pool (Boivin et al., 2016), it is possible that IAA and CKs contribute to the life cycle of $P$. savastano $i$ in other, more subtle, unexplored ways.

\section{KNOT FORMATION BY P. savastanoi REQUIRES A FUNCTIONAL TYPE III SECRETION SYSTEM}

The T3SS of pathogenic bacteria infecting animals and plants is responsible for the injection of specialized proteins, called T3SS effectors (T3Es), into the host cytoplasm (Hueck, 1998; Schulmeyer and Yahr, 2017). In bacterial phytopathogens, the T3SS is required for both disease development in susceptible hosts and the triggering of programmed cell death, also called a hypersensitive response (HR), in resistant hosts (Galan and Collmer, 1999; Büttner and He, 2009). Additionally, the T3SS participates in symbiotic Rhizobium-legume interactions, in which it is required for effective nodule formation (Fauvart and Michiels, 2008; Büttner, 2012).

In the $P$. syringae complex, the T3SS is organized in a cluster within a pathogenicity island, which is predominantly located in the bacterial chromosome. This system is composed of 27 structural and regulatory genes, referred to as the $h r p$ cluster (hypersensitive response and pathogenicity), and organized in five operons ( $h r p R S, h r p Z, h r p C, h r p U$, and $h r p J)$ and two independent genes ( $h r p K$ and $h r p L$ ) (Alfano et al., 


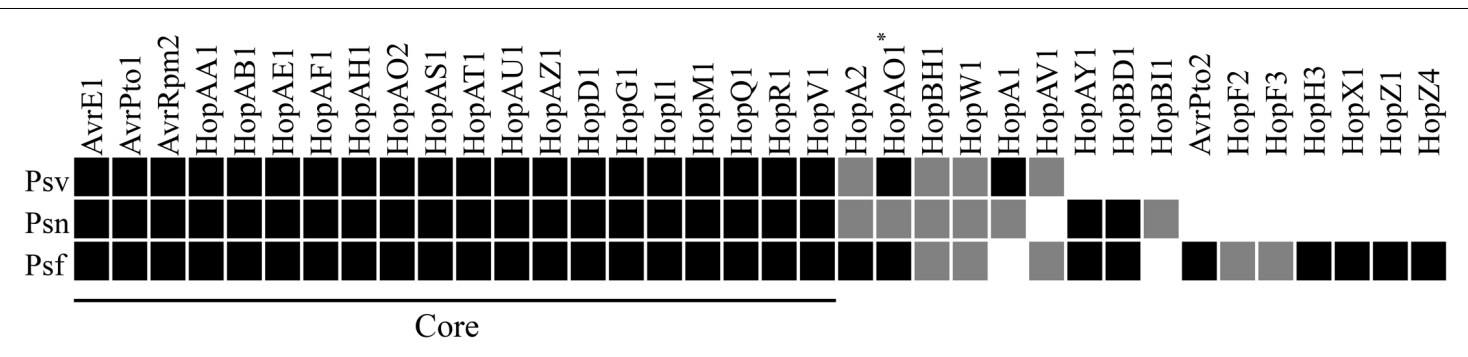

FIGURE 3 | Putative type III effectors (T3Es) identified in Psv NCPPB 3335 (Psv), Psn ICMP 16943 (Psn) and Psf ICMP 7711 (Psf) (Matas et al., 2014 ; Nowell et al., 2016). Black, gray and white boxes indicate presence, possible truncation and absence, respectively, of T3Es in the genomes of these strains. Core refers to the T3Es common among the three strains (excluding truncated proteins). The presence of five Psv NCPPB 3335 T3Es (HopAF1-2*, HopAH2, HopBK1, HopBL1, and HopBL2) has not been investigated in Psn ICMP 16943 and Psf ICMP 7711. Asterisks correspond to plasmid-encoded effectors in Psv NCPPB 3335.

2000; Collmer et al., 2000). Among the hrp cluster, a group of genes highly conserved across plants' and animals' bacterial pathogens has been found; collectively they are called the $h r c$ genes (hypersensitive response and conserved) (Bogdanove et al., 1996). HrpL is one of the most important transcriptional regulators of the T3SS, acting as an activator of the $h r p / h r c$ cluster, most of the T3E genes and their corresponding chaperones, among other genes (Xiao and Hutcheson, 1994; Xiao et al., 1994; Mucyn et al., 2014; Waite et al., 2017). In addition to the canonical T3SS, a group of genes forming an incomplete T3SS, similar to that described in Rhizobium species, has been found in the genomes of several P. syringae and $P$. savastano $i$ isolates (Rodríguez-Palenzuela et al., 2010; Tegli et al., 2011; Baltrus et al., 2017). However, this secondary T3SS has not been related to pathogenicity, and its function remains unclear (Martínez-García et al., 2015).

Although most studies on the role and structure of the T3SS in strains within the $P$. syringae complex have focused on bacteria isolated from herbaceous hosts, $P$. savastanoi also encodes a complete and functional T3SS, which is phylogenetically related to that of other strains of the P. syringae complex (RodríguezPalenzuela et al., 2010; Tegli et al., 2011; Matas et al., 2014; Baltrus et al., 2017). Knot formation in olive trees by Psv has been demonstrated to be dependent on the functionality of the T3SS (Figure 2 and Table 2). A Psv ITM 317-derivative mutant of the $h r c C$ gene, encoding a structural element of the T3SS, was not able to induce a visible HR in Nicotiana tabacum leaves and was impaired in tumor development in olive plants (Sisto et al., 1999, 2004). Similar results have been obtained in woody olive plants for Psv NCPPB 3335 mutants of the hrpA gene (PérezMartínez et al., 2010), encoding the major structural protein of the Hrp pilus and the transcriptional regulatory genes $h r p R$ (Pérez-Martínez et al., 2010; Matas et al., 2012) and hrpL (Matas et al., 2014).

Even though the mechanisms by which a great number of T3Es interfere with plant immunity remain unknown, the T3E repertoire of phytopathogenic bacteria is one of the most relevant factors in determining host range (Baltrus et al., 2011). In silico analyses of several P. savastanoi strains have identified a pool of putative T3Es encoded by Psv NCPPB 3335, Psn ICMP 16943 and Psf ICMP 7711, which are composed of 31, 28, and 34 proteins, respectively (Figure 3) (Rodríguez-Palenzuela et al.,
2010; Ramos et al., 2012; Matas et al., 2014; Nowell et al., 2016). A more thorough characterization of the T3E repertoire has been made in Psv NCPPB 3335, resulting in the demonstration of HrpL-dependent transcription and the translocation to the plant cells of eight proteins that exhibit homology with previously described P. syringae T3Es (i.e., AvrRpm2, HopA1, HopAA1, HopAF1-1, HopAF1-2, HopAO1, HopAO2, HopAZ1) and three effectors belonging to two novel T3E families (i.e., HopBK1, HopBL1, and HopBL2) (Matas et al., 2014; Castañeda-Ojeda et al., 2017a,b). Interestingly, hopBL1 and hopBL2 sequences have been uniquely identified in a collection of 31 Psv strains isolated in different countries and in other P. syringae strains isolated from woody hosts; this indicates a relevant role of the HopBL family in bacterial interactions with olive plants and other trees (Matas et al., 2014). Interference with early plant defense responses has been reported for all these eleven Psv NCPPB 3335 T3E. Furthermore, five of these proteins, HopAZ1, HopAF1-2, HopAO1, HopAO2, and HopBL1, also inhibit effector-triggered immunity (Matas et al., 2014; Castañeda-Ojeda et al., 2017a,b). Moreover, and in agreement with their role in the suppression of early plant defenses, HopAF1-1 and HopAF1-2 have been shown to localize in the plant plasma membrane (Castañeda-Ojeda et al., 2017a). On the other hand, HopAO1 and HopAO2 have been reported to possess phosphatase activity, a distinguishing characteristic of the members of the HopAO family. Deletion of the hopAO1 gene in NCPPB 3335 resulted in reduced virulence in olive plants (Table 2) (Castañeda-Ojeda et al., 2017b). Additional studies are required to identify the complete T3E repertoires of $P$. savastanoi strains isolated from different hosts and to determine their role in regulating knot size and host range.

\section{CYCLIC di-GMP LEVELS IMPACT THE MOTILE TO SESSILE SWITCH IN $P$ savastanoi AND MODULATE VIRULENCE AND KNOT SIZE}

Cyclic di-GMP (c-di-GMP), an ubiquitous and wellcharacterized bacterial secondary messenger, is involved in a wide range of bacterial behaviors, including motility, synthesis and secretion of surface proteins and exopolysaccharides, adhesion 
to host cells, aggregation, biofilm formation and intracellular infection; these behaviors globally influence bacterial virulence of human, animal, and plant pathogens (Dow et al., 2006; Jenal and Malone, 2006; Tamayo et al., 2007; Lee et al., 2010; Yi et al., 2010; Yang et al., 2012; Huang et al., 2013; Perez-Mendoza et al., 2014). Synthesis of c-di-GMP is mediated by diguanylate cyclases (DGCs), mainly associated with GGDEF domains (Pei and Grishin, 2001), while phosphodiesterases (PDEs) are responsible for the hydrolysis of the secondary molecule through EAL or HD-GYP domains (Ryan et al., 2009; Sultan et al., 2011). C-di-GMP signaling, including characteristic signal-input domains of these enzymes and protein effectors, has been widely discussed previously and have highlighted the significance of environmental signals in c-di-GMP-related phenotypes (Romling et al., 2005; Krasteva et al., 2012; Sondermann et al., 2012; Valentini and Filloux, 2016).

The impact of c-di-GMP in the virulence of plant pathogenic bacteria, including Xanthomonas campestris, Dickeya dadantii, Erwinia amylovora, Xylella fastidiosa, Pectobacterium atrosepticum, and bacteria from the $P$. syringae complex, has been recently reviewed (Ham, 2013; Ryan, 2013; Martínez-Gil and Ramos, 2017). In P. syringae pv. tomato DC3000, high levels of the secondary messenger caused by the DGC Chp8 have been related to active evasion of the plant's immunity, decreasing flagellin and increasing production of extracellular polysaccharides (Engl et al., 2014; Pfeilmeier et al., 2016). BifA, a conserved PDE previously identified in P. aeruginosa (Kuchma et al., 2007; Jimenez-Fernandez et al., 2015), has been connected to flagellar motility, fitness and virulence of this tomato pathogen (Aragón et al., 2015a). Furthermore, a recent study identified AmrZ, a novel transcriptional regulator involved in DC3000 pathogenesis, which controls two putative c-di-GMP metabolic enzymes, AdcA and MorA (Prada-Ramirez et al., 2016).

An in silico analysis of the draft genome of Psv NCPPB 3335 revealed the presence of 34 GGDEF- or GGDEF/EAL-containing proteins, which could be related to c-di-GMP metabolism in this phytopathogen (Rodríguez-Palenzuela et al., 2010). The first studies carried out to evaluate the role of c-di-GMP in $P$. savastanoi used the active DGC PleD from Caulobacter crescentus (Aldridge et al., 2003; Perez-Mendoza et al., 2014). The increase of c-di-GMP due to pleD overexpression caused reduced swimming motility and an increase in tumor size, although histological sections of knots that developed in woody olive plants showed a reduction of the necrotic area (PerezMendoza et al., 2014). Intriguingly, no differences were observed in the production of IAA or the expression of the T3SS in this strain, suggesting an additional and yet unknown bacterial factor contributing to knot development that is controlled by PleD. Another study demonstrated the role of DgcP, a conserved DGC in pseudomonads, in knot development by Psv NCPPB 3335 (Aragón et al., 2015b). A mutant in $d g c P$ caused approximately a three-fold decrease in the size of knots induced in olive plants (Figure 2) (Aragón et al., 2015b). Furthermore, the lack of $d g c P$ led to an altered motile/sessile phenotype compared with the wild-type strain; it exhibited increased swimming motility and decreased biofilm formation, likely through changes in exopolysaccharide production (Aragón et al., 2015b). In the same study, a decrease in the expression of the T6SS genes $h c p 1$ and $\operatorname{vgrG}$ was observed in the $d g c P$ mutant, although no significant differences were detected in the expression of the T3SS genes $h r p A, h r p L$, and hopBL1 (Aragón et al., 2015b). On the other hand, the role of the previously described PDE BifA was evaluated with respect to tumor development in $P$. savastanoi (Aragón et al., 2015a). Deletion of bifA impaired swimming motility and decreased tumor size, although exopolysaccharide production and biofilm formation were not affected, which differs from results in other pseudomonads (Kuchma et al., 2007; Jimenez-Fernandez et al., 2015). In contrast, bifA overexpression reduced biofilm formation and exopolysaccharide synthesis, promoting swimming motility and positively regulating host invasion (Aragón et al., 2015a). Further studies on the molecular mechanisms underlying changes in cellular levels of c-di-GMP are necessary to fully comprehend how and when during the infection process this secondary messenger affects $P$. savastanoi virulence and tumor development.

\section{A WHOP MAKES THE DIFFERENCE: METABOLISM OF PHENOLIC COMPOUNDS IS ESSENTIAL FOR $P$. savastanoi INDUCTION OF FULL-SIZE
KNOTS IN WOODY HOSTS}

Host adaptation and specialization of bacterial pathogens frequently involve gain, loss and evolution of virulence genes. Comparative genomic analyses among different bacterial strains constitute a fast and worthwhile approach for the identification of gene clusters putatively related to host adaptation. In the early 2010s, a $15 \mathrm{~kb}$ gene cluster was identified in Psv NCPPB 3335 (Rodríguez-Palenzuela et al., 2010) and in four strains of P. syringae pv. aesculi isolated from horse chestnut (Green et al., 2010), and found to be absent in the genomes of $P$. syringae strains infecting herbaceous hosts. Subsequent genomic analyses determined that the presence of this cluster, currently referred to as the WHOP region (from woody host and $\underline{P}$ seudomonas) (Caballo-Ponce et al., 2017), is a feature exclusive to strains of phylogroups (PGs) 1 and 3 of the P. syringae complex isolated from woody organs of woody hosts, suggesting a specific role of this region in bacterial adaptation to woody tissues (Ramos et al., 2012; Bartoli et al., 2015; Nowell et al., 2016; Caballo-Ponce et al., 2017). In agreement with this hypothesis, the ability of several strains of the P. syringae complex, including Psv strains NCPPB 3335 and PseNe107, to grow endophytically in kiwi trees has been associated with codification of the cat operon (Bartoli et al., 2015).

A recent study delved into the genetic organization, function and role in planta of the WHOP region in Psv NCPPB 3335. Genes in this region are organized into four different operons (cat $B C A$, ant $A B C$, ipo $A B C$, and $d h o A B$ ) and three independently transcribed genes (antR, ben $R$ and a gene encoding a putative aerotaxis receptor). Although no function has yet been attributed to the $d h o A B$ operon, the involvement of the Psv NCPPB 3335 ant $A B C$ and cat $B C A$ operons in the catabolism of anthranilic acid and catechol, respectively, has been confirmed; additionally, the 
ipo $A B C$ operon was associated to an oxygenase activity acting on aromatic compounds (Caballo-Ponce et al., 2017). Nonetheless, the most intriguing conclusions of this work are derived from the role of the WHOP region during bacterial interactions with olive plants. While deletion of several WHOP genes had no effect on the size of knots induced by Psv NCPPB 3335 in micropropagated (i.e., non-woody) olive plants, mutations in the ant $A B C$, catBCA, or ipo $A B C$ operons in Psv resulted in virulence attenuation in woody olive plants (Figure 2). Additionally, a defect in competitive growth in planta was observed for the Psv cat $B C A$ and $d h o A B$ mutants, as well as for the mutant affected in the putative aerotaxis receptor. However, this growth defect was exclusively observed in woody olive plants. Lignin, a complex organic network composed of different aromatic monomers (Boerjan et al., 2003; Ralph et al., 2004), accounts for up to 35\% of the composition of wood (Pettersen, 1984). In fact, many lignin-related aromatic compounds are funneled into catechol and protocatechuate prior to their assimilation through the $\beta$-ketoadipate pathway (Harwood and Parales, 1996). While the machinery for protocatechuate degradation is widespread among $P$. syringae pathovars, the degradation of catechol into Krebs cycle intermediaries is generally restricted to strains of the $P$. syringae complex carrying the WHOP region (Caballo-Ponce et al., 2017). Hence, activities encoded in this region might provide additional pathways for the degradation of specific lignin-related compounds, allowing for the colonization of woody tissues by $P$. savastanoi and other strains of the $P$. syringae complex.

\section{BACTERIAL COMMUNICATION INSIDE THE KNOTS AND THE INFLUENCE OF THE KNOT MICROBIOME ON KNOT DEVELOPMENT}

Although the study of bacterial plant diseases has traditionally focused on single pathogenic strains, in nature, most bacteria live as members of multispecies communities. To address this, the olive knot microbiome has recently been established as a model to study the role of interspecies bacterial communities in plant disease (Buonaurio et al., 2015). Metagenomic analysis of olive knots collected in Italy recently revealed the existence of a complex and diverse microbiome in this plant disease (Passos da Silva et al., 2014). The main constituents of this bacterial community are Pseudomonas spp. and Pantoea spp., with Psv making up almost $50 \%$ of the bacterial load. Although the proportion of other genera varied among samples, a common core composed of Clavibacter, Curtobacterium, Enterobacter, Erwinia, Hymenobacter, Kineococcus, Pectobacterium, and Sphingomonas was conserved in knots from different olive cultivars cultivated in diverse locations (Passos da Silva et al., 2014). Traditional culture methods have allowed identification at the species level of three non-pathogenic bacteria that co-reside with Psv within the olive knot, i.e., Pantoea agglomerans (Marchi et al., 2006), Erwinia toletana (Rojas et al., 2004) and Erwinia oleae (Moretti et al., 2011). Considering such biodiversity, it was reasonable to hypothesize that interspecies communication may occur within the olive knot and might influence the pathogenic behavior of Psv. In fact, three syntrophic pathways for the catabolism of plant-derived compounds have been predicted for the E. toletana-Psv consortium. For instance, the plant hormone salicylic acid, synthesized in response to a pathogenic infection (Loake and Grant, 2007), might be degraded via catechol by the cooperative action of these bacteria. In agreement with this hypothesis is the intimate co-localization of E. toletana and Psv within the olive knot, which may allow the interchange of public goods (Passos da Silva et al., 2014). Thus, combined metabolic features of Psv and E. toletana could both hamper plant defense responses against pathogens (easing the infection process) and diminish the toxicity of compounds generated during the process, leading to the increased bacterial populations observed in co-inoculation experiments (Hosni et al., 2011).

In addition to taking advantage of cooperative metabolism, interspecies cross-communication among bacteria occurs within the olive knot disease by sharing quorum sensing signals (Hosni et al., 2011). The quorum sensing system is a cell densitydependent gene regulatory network that relies on the production and detection of signal molecules, named acyl-homoserine lactones (AHLs) in Gram-negative bacteria, and that is often required for pathogenesis in plant diseases (Von Bodman et al., 2003). Interestingly, E. toletana DAPP-PG 735 and Psv DAPP-PG 722 produce the same types of AHLs (3-oxo-C6- and 3-oxoC8-homoserine lactones). Production of AHL in Psv DAPP-PG 722 is a key feature in the normal generation of knots, as evidenced by the observation that a luxI mutant (i.e., unable to produce AHLs) of this strain induced only stem swelling in olive plants. Interestingly, co-inoculation of this Psv luxI mutant with E. toletana yielded a knot similar in size to that induced by the parental Psv strain, while restoration of knot size did not occur when the Psv luxI mutant was inoculated in combination with an E. toletana luxI mutant (Hosni et al., 2011). Similar pairwise inoculations were carried out between the Psv luxI mutant and a wild type $P$. agglomerans strain, resulting in only partial restoration of knot size. In fact, $P$. agglomerans DAPP-PG 734 synthesizes two types of AHLs (C4- and C6homoserine lactones) that are structurally distinct from those produced by Psv (Hosni et al., 2011). Nevertheless, taking into account the versatility of the AHL-receptor proteins of the LuxR family, which are often capable of responding to structurally different AHLs (Subramoni and Venturi, 2009; Coutinho et al., 2013), the possibility that Psv reacts to the AHLs produced by $P$. agglomerans cannot be excluded. The quorum sensing regulon of this bacterial consortium, however, remains unknown.

\section{ADDITIONAL FACTORS INVOLVED IN $P$ savastanoi-INDUCED OLIVE KNOTS}

In addition to the aforementioned pathogenicity and virulence factors of $P$. savastanoi involved in knot formation, additional molecular mechanisms and metabolic pathways required for the full fitness and virulence of Psv in olive plants have been identified. Application of signature-tagged mutagenesis to Psv NCPPB 3335 during colonization of olive knots (Matas 
et al., 2012) identified the following: 18 genes involved in the biosynthetic pathways of nine of the 20 amino acids found in proteins, five genes related to the biosynthesis of the vitamins biotin, cobalamin, and thiamine, and three genes encoding putative citrate, sulfate and amino acid transporters. In addition to T3SS genes, this strategy also identified type II and IV secretion system genes as essential for full knot formation. Other Psv genes involved in knot formation and identified in this study, were deduced from mutants in a battery of genes involved in the tolerance and detoxification of reactive oxygen species, a set of genes required for the biosynthesis of the cell wall, a gene encoding a methyl-accepting chemotaxis protein, genes for several DNA-related proteins and numerous genes coding for proteins with unknown function (Matas et al., 2012). Although the roles of most of these additional factors in P. savastanoiinduced olive knots have not yet been studied in detail, this strategy provided confirmation of functional capabilities long believed to play a role in the virulence of $P$. syringae and related pathogens that have not yet been sufficiently examined.

\section{CONCLUDING REMARKS}

Since the discovery of the bacterial etiology of certain plant galls, research on the molecular determinants of bacterial gall formation has predominantly focused on the soil and rhizosphere bacterial species $A$. tumefaciens, mainly due to its biotechnological relevance in plant breeding and transformation. Although diverse gall-forming bacteria shared essential determinants involved in gall formation, such as the production of phytohormones, various bacteria also use a distinctive set of molecular mechanisms to survive within the plant tissues and produce galls, which are dependent on their lifestyles and the specific plant tissues they infect. In this sense, $P$. savastanoi strains isolated from woody hosts exhibit a unique lifecycle among all other gall-forming bacteria, involving an epiphytic phase and an endopathogenic stage; the latter takes place predominantly inside trunks, stems and branches.

The discovery of the first mechanism involved in the generation of $P$. savastanoi-induced knots, the tryptophandependent IAA biosynthetic pathway via indole-3-acetamide, as well as the biosynthesis of IAA-Lys by certain P. savastano $i$ strains, dates back approximately four decades. However, the alternative IAA pathway remaining in Psv mutant strains lacking the iaaMH operon, as well as the function and role of the iaaL gene in this $P$. savastanoi pathovar, remains unresolved. Additionally, the role of the ptz gene in the biosynthesis of CKs is currently presumed only from experiments that involved the curing of ptz-encoding plasmids. Metabolomics analyses of the diversity of CKs and IAA-related compounds produced by $P$. savastanoi $p t z$ and iaaMH mutants, respectively, are required to identify alternative biosynthetic pathways for these phytohormones.

Bioinformatics analyses of the putative T3E repertoires encoded in the genomes of diverse $P$. savastanoi strains have recently defined a core of approximately 20 T3Es shared among $P$. savastanoi pathovars isolated from diverse hosts. Further comparative analyses using a higher number of genomes are necessary to determine the specific T3Es encoded by strains isolated from diverse hosts and to approach their role during the infection of woody hosts.

The recent discovery of the role of c-di-GMP in the formation of Psv-induced knots in olive plants leads to further exploration and functional analysis of the large number of DGC and PDE proteins encoded in the genomes of $P$. savastanoi strains, with the aim of establishing their role in the lifestyle of this pathogen. The identification of the specific targets of these enzymes would also help us ascertain the signaling pathways interconnecting c-diGMP with other bacterial processes contributing to virulence, and also to establish their role in knot formation. Since the discovery of the WHOP region in the genome of Psv and $P$. syringae pv. aesculi in the early 2010's, a role of this genomic cluster in the adaptation of bacteria from the P. syringae complex to woody hosts has been suggested by several authors. Despite emerging evidences supporting this hypothesis over the last 2 years, the specific function of the WHOP region during the colonization of woody organs remains to be elucidated. Several functions have been suggested for the WHOP-encoded activities that might explain the advantage conferred by this region to $P$. savastanoi, including, (i) the assimilation of ligninrelated compounds, (ii) the modification of certain compounds to decrease their toxicity, and (iii) interference with the IAA pool, influencing virulence and thus knot size. However, all these hypotheses remain to be critically tested. Further studies are also needed to fully understand the mechanisms involved in the interspecies synergism established within the microbial community in knots. To this end, metagenomic analyses of knot microbiomes from diverse hosts might help to generate new hypotheses that aid in our understanding of the signaling pathways shared among diverse microbial species and the possible metabolic complementarity established among them.

A great deal of research is still necessary to establish approaches to understand the evolution and adaptation of $P$. savastanoi to novel hosts and to develop effective control strategies for $P$. savastanoi-induced knot diseases. We perceive the following priority areas for future research on the interaction of $P$. savastano $i$ with woody hosts:

(1) The dissection of all metabolic routes for the biosynthesis of phytohormones and of the resulting biologically active compounds. This will facilitate the identification of the likely role of phytohormones in the regulation of virulence genes, the suppression of plant defense responses and the survival of $P$. savastanoi, both during infection and epiphytically.

(2) The identification of T3SS effectors specifically required for the infection of woody hosts, and the determination of their role in host specificity.

(3) The discovery of new types of genes that deeply influence virulence is changing our understanding of pathogenicity and the mechanisms underlying host specificity. Research in the many roles of c-di-GMP in virulence, and the specific functions of the WHOP region should illuminate the infection process and the contribution of plant phenolics to defense. 
(4) The simplification of pathosystems has been critical for the dissection of pathogenicity, but is increasingly clear that the interactions between plants and pathogens are influenced by a potentially diverse community of microorganisms. The metagenomics analyses of these communities will propel our understanding of a further organizational level that, ultimately, determines whether the outcome is disease or a plentiful harvest.

\section{AUTHOR CONTRIBUTIONS}

All authors contributed to manuscript writing and elaboration of Figures and Tables.

\section{FUNDING}

This work was supported by the Spanish Plan Nacional $\mathrm{I}+\mathrm{D}+\mathrm{i}$ grants AGL2014-53242-C2-1-R and AGL2014-53242-C2-2-R

\section{REFERENCES}

Agrios, G. (2005). Plant Pathology. San Diego, CA: Elsevier.

Aldridge, P., Paul, R., Goymer, P., Rainey, P., and Jenal, U. (2003). Role of the GGDEF regulator PleD in polar development of Caulobacter crescentus. Mol. Microbiol. 47, 1695-1708. doi: 10.1046/j.1365-2958.2003.03401.x

Alfano, J. R., Charkowski, A. O., Deng, W.-L., Badel, J. L., Petnicki-Ocwieja, T., Van Dijk, K., et al. (2000). The Pseudomonas syringae Hrp pathogenicity island has a tripartite mosaic structure composed of a cluster of type III secretion genes bounded by exchangeable effector and conserved effector loci that contribute to parasitic fitness and pathogenicity in plants. Proc. Natl. Acad. Sci. U.S.A. 97, 4856-4861. doi: 10.1073/pnas.97.9.4856

Aloni, R., Pradel, K. S., and Ullrich, C. I. (1995). The three-dimensional structure of vascular tissues in Agrobacterium tumefaciens-induced crown galls and in the host stems of Ricinus communis L. Planta 196, 597-605. doi: 10.1007/ bf00203661

Alvarez, F., García De Los Ríos, J. E., Jimenez, P., Rojas, A., Reche, P., and Troya, M. T. (1998). Phenotypic variability in different strains of Pseudomonas syringae subsp. savastanoi isolated from different hosts. Eur. J. Plant. Pathol. 104, 603-609. doi: 10.1023/a:1008604011154

Aragón, I. M., Pérez-Martínez, I., Moreno-Perez, A., Cerezo, M., and Ramos, C. (2014). New insights into the role of indole-3-acetic acid in the virulence of Pseudomonas savastanoi pv. savastanoi. FEMS Microbiol. Lett. 356, 184-192. doi: 10.1111/1574-6968.12413

Aragón, I. M., Perez-Mendoza, D., Gallegos, M. T., and Ramos, C. (2015a). The c-di-GMP phosphodiesterase BifA is involved in the virulence of bacteria from the Pseudomonas syringae complex. Mol. Plant. Pathol. 16, 604-615. doi: 10. 1111/mpp.12218

Aragón, I. M., Perez-Mendoza, D., Moscoso, J. A., Faure, E., Guery, B., Gallegos, M. T., et al. (2015b). Diguanylate cyclase DgcP is involved in plant and human Pseudomonas spp. infections. Environ. Microbiol. 17, 4332-4351. doi: 10.1111/ $1462-2920.12856$

Arkhipova, T. N., Prinsen, E., Veselov, S. U., Martinenko, E. V., Melentiev, A. I., and Kudoyarova, G. R. (2007). Cytokinin producing bacteria enhance plant growth in drying soil. Plant Soil 292, 305-315. doi: 10.1007/s11104-007-9233-5

Baltrus, D. A., Mccann, H. C., and Guttman, D. S. (2017). Evolution, genomics and epidemiology of Pseudomonas syringae. Mol. Plant Pathol. 18, 152-168. doi: $10.1111 / \mathrm{mpp} .12506$

Baltrus, D. A., Nishimura, M. T., Romanchuk, A., Chang, J. H., Mukhtar, M. S., and Cherkis, K. (2011). Dynamic evolution of pathogenicity revealed by sequencing and comparative genomics of 19 Pseudomonas syringae isolates. PLoS Pathog. 7:e1002132. doi: 10.1371/journal.ppat.1002132 from the Spanish Ministerio de Economía y Competitividad (MINECO) and was co-financed by FEDER. AP was supported by a FPU Ph.D. fellowship and AM-P and EC-P by FPI Ph.D. fellowships from the Spanish Ministerio de Educación, Cultura y Deporte (MECD) and MINECO.

\section{ACKNOWLEDGMENTS}

We are grateful to I. Pérez-Martínez, L. Rodríguez-Moreno, L. Lambertsen, I. M. Matas, I. M. Aragón and M. P. CastañedaOjeda for their previous work on $P$. savastanoi at the University of Málaga (Spain), to L. Bardaji and M. Añorga for their contribution at the Universidad Pública de Navarra (Spain) and to P. Rodríguez-Palenzuela and E. López-Solanilla (Universidad Politécnica de Madrid, Spain) for their support to this research line. We are thankful to L. Rodríguez-Moreno for providing Figures 1D,E. The authors thank Theresa H. Osinga for critical reading of the manuscript and advice on English usage.

Barash, I., and Manulis-Sasson, S. (2007). Virulence mechanisms and host specificity of gall-forming Pantoea agglomerans. Trends Microbiol. 15, 538-545. doi: 10.1016/j.tim.2007.10.009

Bardaji, L., Pérez-Martínez, I., Rodríguez-Moreno, L., Rodríguez-Palenzuela, P., Sundin, G. W., Ramos, C., et al. (2011). Sequence and role in virulence of the three plasmid complement of the model tumor-inducing bacterium Pseudomonas savastanoi pv. savastanoi NCPPB 3335. PLoS ONE 6:e25705. doi: 10.1371/journal.pone.0025705

Bartoli, C., Lamichhane, J. R., Berge, O., Guilbaud, C., Varvaro, L., Balestra, G. M., et al. (2015). A framework to gauge the epidemic potential of plant pathogens in environmental reservoirs: the example of kiwifruit canker. Mol. Plant Pathol. 16, 137-149. doi: 10.1111/mpp.12167

Boerjan, W., Ralph, J., and Baucher, M. (2003). Lignin biosynthesis. Annu. Rev. Plant Biol. 54, 519-546. doi: 10.1146/annurev.arplant.54.031902.134938

Bogdanove, A. J., Beer, S. V., Bonas, U., Boucher, C. A., Collmer, A., Coplin, D. L., et al. (1996). Unified nomenclature for broadly conserved hrp genes of phytopathogenic bacteria. Mol. Microbiol. 20, 681-683. doi: 10.1046/j.13652958.1996.5731077.x

Boivin, S., Fonouni-Farde, C., and Frugier, F. (2016). How auxin and cytokinin phytohormones modulate root microbe interactions. Front. Plant Sci. 7:1240. doi: 10.3389/fpls.2016.01240

Bozkurt, I. A., Soylu, S., Mirik, M., Ulubas Serce, C., and Baysal, O. (2014). Characterization of bacterial knot disease caused by Pseudomonas savastanoi pv. savastanoi on pomegranate (Punica granatum L.) trees: a new host of the pathogen. Lett. Appl. Microbiol. 59, 520-527. doi: 10.1111/lam.12309

Bradbury, J. F. (1986). Guide to Plant Pathogenic Bacteria. Wallingford: CAB International.

Bull, C. T., De Boer, S. H., Denny, T. P., Firrao, G., Fischer-Le Saux, M., Saddler, G. S., et al. (2010). Comprehensive list of names of plant pathogenic bacteria, 1980-2007. J. Plant Pathol. 92, 551-592.

Buonaurio, R., Moretti, C., Passos da Silva, D., Cortese, C., Ramos, C., and Venturi, V. (2015). The olive knot disease as a model to study the role of interspecies bacterial communities in plant disease. Front. Plant Sci. 6:434. doi: $10.3389 /$ fpls.2015.00434

Büttner, D. (2012). Protein export according to schedule: architecture, assembly, and regulation of type III secretion systems from plant- and animal-pathogenic bacteria. Microbiol. Mol. Biol. Rev. 76, 262-310. doi: 10.1128/MMBR.05017-11

Büttner, D., and He, S. Y. (2009). Type III protein secretion in plant pathogenic bacteria. Plant Physiol. 150, 1656-1664. doi: 10.1104/pp.109.139089

Caballo-Ponce, E., and Ramos, C. (2016). First report of dipladenia (Mandevilla spp.) leaf and stem spot caused by Pseudomonas savastanoi in Spain. Plant Dis. 100, 2319. doi: 10.1094/PDIS-03-16-0334-PDN 
Caballo-Ponce, E., Van Dillewijn, P., Wittich, R.-M., and Ramos, C. (2017). WHOP, a genomic region associated with woody hosts in the Pseudomonas syringae complex contributes to the virulence and fitness of Pseudomonas savastanoi pv. savastanoi in olive plants. Mol. Plant Microbe Interact. 30, 113-126. doi: 10.1094/MPMI-11-16-0233-R

Caponero, A., Contesini, A. M., and Iacobellis, N. S. (1995). Population diversity of Pseudomonas syringae subsp. savastanoi on olive and oleander. Plant Pathol. 44, 848-855. doi: 10.1111/j.1365-3059.1995.tb02744.x

Castañeda-Ojeda, M. P., López-Solanilla, E., and Ramos, C. (2017a). Differential modulation of plant immune responses by diverse members of the Pseudomonas savastanoi pv. savastanoi HopAF type III effector family. Mol. Plant Pathol. 18, 625-634. doi: 10.1111/mpp.12420

Castañeda-Ojeda, M. P., Moreno-Pérez, A., López-Solanilla, E., and Ramos, C. (2017b). Suppression of plant immune responses by the Pseudomonas savastanoi pv. savastanoi NCPPB 3335 type III effector tyrosine phosphatases HopAO1 and HopAO2. Front. Plant Sci. 8:680. doi: 10.3389/fpls.2017.00680

Castillo-Lizardo, M. G., Aragón, I. M., Carvajal, V., Matas, I. M., Perez-Bueno, M. L., Gallegos, M. T., et al. (2015). Contribution of the non-effector members of the HrpL regulon, iaaL and matE, to the virulence of Pseudomonas syringae pv. tomato DC3000 in tomato plants. BMC Microbiol. 15:165. doi: 10.1186/ s12866-015-0503-8

Cavara, F. (1897). Tubercolosi della vite. Intorno alla eziologia de alcune malattie di piante coltivate. Stazioni Sperimentali Agrarie Italiane 30, 483-487.

Cerboneschi, M., Decorosi, F., Biancalani, C., Ortenzi, M. V., Macconi, S., Giovannetti, L., et al. (2016). Indole-3-acetic acid in plant-pathogen interactions: a key molecule for in planta bacterial virulence and fitness. Res. Microbiol. 167, 774-787. doi: 10.1016/j.resmic.2016.09.002

Chalupowicz, L., Barash, I., Panijel, M., Sessa, G., and Manulis-Sasson, S. (2009). Regulatory interactions between quorum-sensing, auxin, cytokinin, and the Hrp regulon in relation to gall formation and epiphytic fitness of Pantoea agglomerans pv. gypsophilae. Mol. Plant Microbe Interact. 22, 849-856. doi: 10.1094/MPMI-22-7-0849

Chilton, M., Drummond, M., Merlo, D., Sciaky, D., Montoya, A., Gordon, M., et al. (1977). Stable incorporation of plasmid DNA into higher plant cells: the molecular basis of crown gall tumorigenesis. Cell 11, 263-271. doi: 10.1016/ 0092-8674(77)90043-5

Cinelli, T., Marchi, G., Cimmino, A., Marongiu, R., Evidente, A., and Fiori, M. (2014). Heterogeneity of Pseudomonas savastanoi populations infecting Myrtus communis in Sardinia (Italy). Plant Pathol. 63, 277-289. doi: 10.1111/ppa. 12096

Cinelli, T., Rizzo, D., Marchi, G., and Surico, G. (2013). First report of knot disease caused by Pseudomonas savastanoi on sweet olive in Central Italy. Plant. Dis. 97:419. doi: 10.1094/pdis-09-12-0818-pdn

Collmer, A., Badel, J. L., Charkowski, A. O., Deng, W. L., Fouts, D. E., Ramos, A. R., et al. (2000). Pseudomonas syringae Hrp type III secretion system and effector proteins. Proc. Natl. Acad. Sci. U.S.A. 97, 8770-8777. doi: 10.1073/pnas.97.16. 8770

Comai, L., and Kosuge, T. (1980). Involvement of plasmid deoxyribonucleic acid in indoleacetic acid synthesis in Pseudomonas savastanoi. J. Bacteriol. 143, 950-957.

Comai, L., Surico, G., and Kosuge, T. (1992). Relation of plasmid DNA to indoleacetic acid production in different strains of Pseudomonas syringae pv. savastanoi. Microbiology 128, 2157-2163. doi: 10.1099/00221287-1289-2157

Coutinho, B. G., Mitter, B., Talbi, C., Sessitsch, A., Bedmar, E. J., Halliday, N., et al. (2013). Regulon studies and in planta role of the BraI/R quorum-sensing system in the plant-beneficial Burkholderia cluster. Appl. Environ. Microbiol. 79, 4421-4432. doi: 10.1128/AEM.00635-13

Dow, J. M., Fouhy, Y., Lucey, J. F., and Ryan, R. P. (2006). The HD-GYP domain, cyclic di-GMP signaling, and bacterial virulence to plants. Mol. Plant Microbe Interact. 19, 1378-1384. doi: 10.1094/MPMI-19-1378

Eltlbany, N., Prokscha, Z. Z., Castañeda-Ojeda, M. P., Krogerrecklenfort, E., Heuer, H., Wohanka, W., et al. (2012). A new bacterial disease on Mandevilla sanderi, caused by Pseudomonas savastanoi: lessons learned for bacterial diversity studies. Appl. Environ. Microbiol. 78, 8492-8497. doi: 10.1128/AEM. 02049- 12

Engl, C., Waite, C. J., Mckenna, J. F., Bennett, M. H., Hamann, T., and Buck, M. (2014). Chp8, a diguanylate cyclase from Pseudomonas syringae pv. tomato DC3000, suppresses the pathogen-associated molecular pattern flagellin, increases extracellular polysaccharides, and promotes plant immune evasion. mBio 5:e1168-14. doi: 10.1128/mBio.01168-14

Ercolani, G. L. (1978). Pseudomonas savastanoi and other bacteria colonizing the surface of olive leaves in the field. Microbiology 109, 245-257. doi: 10.1099/ 00221287-109-2-245

Evidente, A., Surico, G., Iacobellis, N. S., and Randazzo, G. (1985). $\alpha-N-$ acetyl-indole-3-acetyl- $\varepsilon$-L-lysine: a metabolite of indole-3-acetic acid from Pseudomonas syringae pv. savastanoi. Phytochemistry 25, 125-128. doi: 10.1016/ S0031-9422(00)94515-1

Evidente, A., Suricot, G., Iacobellis, N. S., and Randazzo, G. (1986). 1 '-methyl-zeatin, an additional cytokinin from Pseudomonas syringae pv. savastanoi. Phytochemistry 25, 525-526. doi: 10.1016/S0031-9422(00) 85515-6

Fauvart, M., and Michiels, J. (2008). Rhizobial secreted proteins as determinants of host specificity in the Rhizobium-legume symbiosis. FEMS Microbiol. Lett. 285, 1-9. doi: 10.1111/j.1574-6968.2008.01254.x

Galan, J. E., and Collmer, A. (1999). Type III secretion machines: bacterial devices for protein delivery into host cells. Science 284, 1322-1328. doi: 10.1126/science. 284.5418.1322

Gardan, L., Bollet, C., Abu Ghorrah, M., Grimont, F., and Grimont, P. A. D. (1992a). DNA relatedness among the pathovar strains of Pseudomonas syringae subsp. savastanoi Janse (1982) and proposal of Pseudomonas savastanoi sp. nov. Int. J. Syst. Bacteriol. 42, 606-612. doi: 10.1099/00207713-42-4-606

Gardan, L., David, C., Morel, M., Glickmann, E., Abu-Ghorrah, M., Petit, A., et al. (1992b). Evidence for a correlation between auxin production and host plant species among strains of Pseudomonas syringae subsp. savastanoi. Appl. Environ. Microbiol. 58, 1780-1783.

Gardan, L., Shafik, H., Belouin, S., Broch, R., Grimont, F., and Grimont, P. A. D. (1999). DNA relatedness among the pathovars of Pseudomonas syringae and description of Pseudomonas tremae sp. nov. and Pseudomonas cannabina sp. nov. (ex Sutic and Dowson 1959). Int. J. Syst. Bacteriol. 49, 469-478. doi: 10.1099/00207713-49-2-469

Gelvin, S. B. (2003). Agrobacterium-mediated plant transformation: the biology behind the "gene-jockeying" tool. Microbiol. Mol. Biol. Rev. 67, 16-37. doi: $10.1128 / \mathrm{mmbr} .67 .1 .16-37.2003$

Glass, N. L., and Kosuge, T. (1986). Cloning of the gene for indoleacetic acidlysine synthetase from Pseudomonas syringae subsp. savastanoi. J. Bacteriol. 166, 598-603. doi: 10.1128/jb.166.2.598-603.1986

Glass, N. L., and Kosuge, T. (1988). Role of indoleacetic acid-lysine synthetase in regulation of indoleacetic acid pool size and virulence of Pseudomonas syringae subsp. savastanoi. J. Bacteriol. 170, 2367-2373. doi: 10.1128/jb.170.5.2367-2373. 1988

Goethals, K., Vereecke, D., Jaziri, M., Van Montagu, M., and Holsters, M. (2001). Leafy gall formation by Rhodococcus fascians. Annu. Rev. Phytopathol. 39, 27-52. doi: 10.1146/annurev.phyto.39.1.27

Goto, M., and Kuwata, H. (1988). Rhizobacter daucus gen. nov., sp. nov., the causal agent of carrot bacterial gall. Int. J. Syst. Bacteriol. 38, 233-239. doi: 10.1099/00207713-38-3-233

Goumas, D. E., Malathrakis, N. E., and Chatzaki, A. K. (2000). First report of Pseudomonas savastanoi pv. savastanoi on Myrtus communis sp. Phytopathol. Mediterr. 39, 313-338.

Green, S., Studholme, D. J., Laue, B. E., Dorati, F., Lovell, H., Arnold, D., et al. (2010). Comparative genome analysis provides insights into the evolution and adaptation of Pseudomonas syringae pv. aesculi on Aesculus hippocastanum. PLoS ONE 5:e10224. doi: 10.1371/journal.pone.0010224

Ham, J. H. (2013). Intercellular and intracellular signalling systems that globally control the expression of virulence genes in plant pathogenic bacteria. Mol. Plant Pathol. 14, 308-322. doi: 10.1111/mpp.12005

Harwood, C. S., and Parales, R. E. (1996). The beta-ketoadipate pathway and the biology of self-identity. Annu. Rev. Microbiol. 50, 553-590. doi: 10.1146/ annurev.micro.50.1.553

Hosni, T., Moretti, C., Devescovi, G., Suarez-Moreno, Z. R., Fatmi, M. B., Guarnaccia, C., et al. (2011). Sharing of quorum-sensing signals and role of interspecies communities in a bacterial plant disease. ISME J. 5, 1857-1870. doi: 10.1038/ismej.2011.65

Huang, C. J., Wang, Z. C., Huang, H. Y., Huang, H. D., and Peng, H. L. (2013). YjcC, a c-di-GMP phosphodiesterase protein, regulates the oxidative stress 
response and virulence of Klebsiella pneumoniae CG43. PLoS ONE 8:e66740. doi: 10.1371/journal.pone.0066740

Hueck, C. J. (1998). Type III protein secretion systems in bacterial pathogens of animals and plants. Microbiol. Mol. Biol. Rev. 62, 379-433.

Hutzinger, O., and Kosuge, T. (1968). Microbial synthesis and degradation of indole-3-acetic acid. 3. The isolation and characterization of indole-3-acetylepsilon-L-lysine. Biochemistry 7, 601-605. doi: 10.1021/bi00842a013

Hwang, H. H., Yang, F. J., Cheng, T. F., Chen, Y. C., Lee, Y. L., Tsai, Y. L., et al. (2013). The Tzs protein and exogenous cytokinin affect virulence gene expression and bacterial growth of Agrobacterium tumefaciens. Phytopathology 103, 888-899. doi: 10.1094/PHYTO-01-13-0020-R

Iacobellis, N. S. (2001). "Olive knot," in Encyclopedia of Plant Pathology, eds O. C. Maloy and T. D. Murray (New York, NY: John Wiley and sons), 713-715.

Iacobellis, N. S., Caponero, A., and Evidente, A. (1998). Characterization of Pseudomonas syringae ssp. savastanoi strains isolated from ash. Plant Pathol. 47, 73-83. doi: 10.1046/j.1365-3059.1998.00202.x

Iacobellis, N. S., Sisto, A., Surico, G., Evidente, A., and Dimaio, E. (1994). Pathogenicity of Pseudomonas syringae subsp. savastanoi mutants defective in phytohormone production. J. Phytopathol. 140, 238-248. doi: 10.1111/j.14390434.1994.tb04813.x

Janse, J. D. (1980). Symptoms on common ash caused by Pseudomonas savastanoi and several other organisms. Acta Bot. Neerl. 29:214.

Janse, J. D. (1982). Pseudomonas syringae subsp. savastanoi (ex Smith) subsp. nov., nom. rev., the bacterium causing excrescences on Oleaceae and Neriurn oleander L. Int. J. Syst. Evol. Microbiol. 32, 166-169. doi: 10.1099/00207713-322- 166

Jenal, U., and Malone, J. (2006). Mechanisms of cyclic-di-GMP signaling in bacteria. Annu. Rev. Genet. 40, 385-407. doi: 10.1146/annurev.genet.40.110405. 090423

Jimenez-Fernandez, A., Lopez-Sanchez, A., Calero, P., and Govantes, F. (2015). The c-di-GMP phosphodiesterase BifA regulates biofilm development in Pseudomonas putida. Environ. Microbiol. Rep. 7, 78-84. doi: 10.1111/17582229.12153

Kawarazaki, H., Goto, M., Kato, K., Kijima, T., Kawada, H., Yamamoto, K., et al. (2009). Identification of a bacterium isolated from galls on carrot and weeds. J. Gen. Plant Pathol. 75, 235-240. doi: 10.1007/s10327-009-0160-6

Kawarazaki, H., Goto, M., Kato, K., Kijima, T., and Takikawa, Y. (2012). Isolation and plant host range of Rhizobacter dauci, causal agent of carrot bacterial gall. Jpn. J. Phytopathol. 78, 293-300. doi: 10.3186/ijphytopath.78.293

Kieffer, M., Neve, J., and Kepinski, S. (2010). Defining auxin response contexts in plant development. Curr. Opin. Plant Biol. 13, 12-20. doi: 10.1016/j.pbi.2009. 10.006

Kosuge, T., Heskett, M. G., and Wilson, E. E. (1966). Microbial synthesis and degradation of indole-3-acetic acid. I. The conversion of L-tryptophan to indole-3-acetamide by an enzyme system from Pseudomonas savastanoi. J. Biol. Chem. 241, 3738-3744.

Krasteva, P. V., Giglio, K. M., and Sondermann, H. (2012). Sensing the messenger: the diverse ways that bacteria signal through c-di-GMP. Protein Sci. 21, 929-948. doi: 10.1002/pro.2093

Kuchma, S. L., Brothers, K. M., Merritt, J. H., Liberati, N. T., Ausubel, F. M., and O’Toole, G. A. (2007). BifA, a cyclic-Di-GMP phosphodiesterase, inversely regulates biofilm formation and swarming motility by Pseudomonas aeruginosa PA14. J. Bacteriol. 189, 8165-8178. doi: 10.1128/JB.00586-07

Kudoyarova, G. R., Melentiev, A. I., Martynenko, E. V., Timergalina, L. N., Arkhipova, T. N., Shendel, G. V., et al. (2014). Cytokinin producing bacteria stimulate amino acid deposition by wheat roots. Plant Physiol. Biochem. 83, 285-291. doi: 10.1016/j.plaphy.2014.08.015

Lamichhane, J. R., Varvaro, L., Parisi, L., Audergon, J.-M., and Morris, C. E. (2014). "Disease and frost damage of woody plants caused by Pseudomonas syringae: seeing the forest for the trees," in Advances in Agronomy, Vol. 126, ed. D. L. Sparks (San Diego, CA: Academic Press Inc.), 235-295. doi: 10.1016/b978-012-800132-5.00004-3

Lee, H. S., Gu, F., Ching, S. M., Lam, Y., and Chua, K. L. (2010). CdpA is a Burkholderia pseudomallei cyclic di-GMP phosphodiesterase involved in autoaggregation, flagellum synthesis, motility, biofilm formation, cell invasion, and cytotoxicity. Infect. Immun. 78, 1832-1840. doi: 10.1128/iai.00446-09

Loake, G., and Grant, M. (2007). Salicylic acid in plant defence-the players and protagonists. Curr. Opin. Plant Biol. 10, 466-472. doi: 10.1016/j.pbi.2007.08.008
Ma, K.-W., and Ma, W. (2016). Phytohormone pathways as targets of pathogens to facilitate infection. Plant Mol. Biol. 91, 713-725. doi: 10.1007/s11103-0160452-0

MacDonald, E. M., Powell, G. K., Regier, D. A., Glass, N. L., Roberto, F., Kosuge, T., et al. (1986). Secretion of zeatin, ribosylzeatin, and ribosyl-1"-methylzeatin by Pseudomonas savastanoi. Plant Physiol. 82, 742-747. doi: 10.1104/pp.82.3.742

Magie, A. R., Wilson, E. E., and Kosuge, T. (1963). Indoleacetamide as an intermediate in the synthesis of indoleacetic acid in Pseudomonas savastanoi. Science 141, 1281-1282. doi: 10.1126/science.141.3587.1281

Maldonado-González, M. M., Prieto, P., Ramos, C., and Mercado-Blanco, J. (2013). From the root to the stem: interaction between the biocontrol root endophyte Pseudomonas fluorescens PICF7 and the pathogen Pseudomonas savastanoi NCPPB 3335 in olive knots. Microb. Biotechnol. 6, 275-287. doi: 10.1111/17517915.12036

Manulis, S., Haviv-Chesner, A., Brandl, M. T., Lindow, S. E., and Barash, I. (1998). Differential involvement of indole-3-acetic acid biosynthetic pathways in pathogenicity and epiphytic fitness of Erwinia herbicola pv. gypsophilae. Mol. Plant Microbe Interact. 11, 634-642. doi: 10.1094/mpmi.1998.11.7.634

Marchi, G., Sisto, A., Cimmino, A., Andolfi, A., Cipriani, M. G., Evidente, A., et al. (2006). Interaction between Pseudomonas savastanoi pv. savastanoi and Pantoea agglomerans in olive knots. Plant Pathol. 55, 614-624. doi: 10.1111/j. 1365-3059.2006.01449.x

Martínez-García, P. M., Rodríguez-Palenzuela, P., Arrebola, E., Carrión, V. J., Gutiérrez-Barranquero, J. A., Pérez-García, A., et al. (2015). Bioinformatics analysis of the complete genome sequence of the mango tree pathogen Pseudomonas syringae pv. syringae UMAF0158 reveals traits relevant to virulence and epiphytic lifestyle. PLOS ONE 10:e0136101. doi: 10.1371/journal. pone. 0136101

Martínez-Gil, M., and Ramos, C. (2017). "Role of cyclic di-GMP in the bacterial virulence and evasion of the plant immunity," in Bacterial Evasion of the Host Immune System, ed. P. Escoll (Norfolk: Caister Academic Press), 197-218. doi: 10.21775/9781910190692.08

Matas, I. M., Castañeda-Ojeda, M. P., Aragón, I. M., Antúnez-Lamas, M., Murillo, J., Rodríguez-Palenzuela, P., et al. (2014). Translocation and functional analysis of Pseudomonas savastanoi pv. savastanoi NCPPB 3335 Type III secretion system effectors reveals two novel effector families of the Pseudomonas syringae complex. Mol. Plant Microbe Interact. 27, 424-436. doi: 10.1094/ MPMI-07-13-0206-R

Matas, I. M., Lambertsen, L., Rodríguez-Moreno, L., and Ramos, C. (2012). Identification of novel virulence genes and metabolic pathways required for full fitness of Pseudomonas savastanoi pv. savastanoi in olive (Olea europaea) knots. New Phytol. 196, 1182-1196. doi: 10.1111/j.1469-8137.2012. 04357.x

Matas, I. M., Pérez-Martínez, I., Quesada, J. M., Rodríguez-Herva, J. J., Penyalver, R., and Ramos, C. (2009). Pseudomonas savastanoi pv. savastanoi contains two iaaL paralogs, one of which exhibits a variable number of a trinucleotide (TAC) tandem repeat. Appl. Environ. Microbiol. 75, 1030-1035. doi: 10.1128/AEM.01572-08

Mirik, M., Aysan, Y., and Sahin, F. (2011). Characterization of Pseudomonas savastanoi pv. savastanoi strains isolated from several host plants in Turkey and report of fontanesia as a new host. J. Plant Pathol. 93, 263-270.

Moretti, C., Hosni, T., Vandemeulebroecke, K., Brady, C., De Vos, P., Buonaurio, R., et al. (2011). Erwinia oleae sp. nov., isolated from olive knots caused by Pseudomonas savastanoi pv. savastanoi. Int. J. Syst. Evol. Microbiol. 61, 2745-2752. doi: 10.1099/ijs.0.026336-0

Mucyn, T. S., Yourstone, S., Lind, A. L., Biswas, S., Nishimura, M. T., Baltrus, D. A., et al. (2014). Variable suites of non-effector genes are co-regulated in the Type III secretion virulence regulon across the Pseudomonas syringae phylogeny. PLoS Pathog. 10:e1003807. doi: 10.1371/journal.ppat.1003807

Nowell, R. W., Green, S., Laue, B. E., and Sharp, P. M. (2014). The extent of genome flux and its role in the differentiation of bacterial lineages. Genome Biol. Evol. 6, 1514-1529. doi: 10.1093/gbe/evu123

Nowell, R. W., Laue, B. E., Sharp, P. M., and Green, S. (2016). Comparative genomics reveals genes significantly associated with woody hosts in the plant pathogen Pseudomonas syringae. Mol. Plant Pathol. 17, 1409-1424. doi: 10. $1111 /$ mpp. 12423

O’Brien, J. A., and Benková, E. (2013). Cytokinin cross-talking during biotic and abiotic stress responses. Front. Plant Sci. 4:451. doi: 10.3389/fpls.2013.00451 
Palm, C. J., Gaffney, T., and Kosuge, T. (1989). Cotranscription of genes encoding indoleacetic acid production in Pseudomonas syringae subsp. savastanoi. J. Bacteriol. 171, 1002-1009. doi: 10.1128/jb.171.2.1002-1009.1989

Passos da Silva, D., Castañeda-Ojeda, M. P., Moretti, C., Buonaurio, R., Ramos, C., and Venturi, V. (2014). Bacterial multispecies studies and microbiome analysis of a plant disease. Microbiology 160, 556-566. doi: 10.1099/mic.0. 074468-0

Patten, C. L., Blakney, A. J., and Coulson, T. J. (2013). Activity, distribution and function of indole-3-acetic acid biosynthetic pathways in bacteria. Crit. Rev. Microbiol. 39, 395-415. doi: 10.3109/1040841X.2012.716819

Pei, J., and Grishin, N. V. (2001). GGDEF domain is homologous to adenylyl cyclase. Proteins 42, 210-216. doi: 10.1002/1097-0134(20010201)42:2<210: AID-PROT80<3.0.CO;2-8

Pérez-Martínez, I., Rodríguez-Moreno, L., Lambertsen, L., Matas, I. M., Murillo, J., Tegli, S., et al. (2010). Fate of a Pseudomonas savastanoi pv. savastanoi type III secretion system mutant in olive plants (Olea europaea L.). Appl. Environ. Microbiol. 76, 3611-3619. doi: 10.1128/AEM.00133-10

Pérez-Martínez, I., Zhao, Y., Murillo, J., Sundin, G. W., and Ramos, C. (2008). Global genomic analysis of Pseudomonas savastanoi pv. savastanoi plasmids. J. Bacteriol. 190, 625-635. doi: 10.1128/JB.01067-07

Perez-Mendoza, D., Aragón, I. M., Prada-Ramirez, H. A., Romero-Jimenez, L., Ramos, C., Gallegos, M. T., et al. (2014). Responses to elevated c-di-GMP levels in mutualistic and pathogenic plant-interacting bacteria. PLoS ONE 9:e91645. doi: 10.1371/journal.pone.0091645

Pettersen, R. C. (1984). “The chemical composition of wood," in The Chemistry of Solid Wood, ed. R. M. Rowell (Washington, DC: American Chemical Society), 57-126. doi: 10.1021/ba-1984-0207.ch002

Pfeilmeier, S., Saur, I. M., Rathjen, J. P., Zipfel, C., and Malone, J. G. (2016). High levels of cyclic-di-GMP in plant-associated Pseudomonas correlate with evasion of plant immunity. Mol. Plant Pathol. 17, 521-531. doi: 10.1111/mpp.12297

Pierce, N. B. (1891). Tuberculosis of the olive. J. Mycol. 6, 148-153. doi: 10.2307/ 3752657

Pirc, M., Ravnikar, M., and Dreo, T. (2014). First report of Pseudomonas savastanoi causing bacterial leaf spot of Mandevilla sanderi in Slovenia. Plant Dis. 99, 415-415. doi: 10.1094/PDIS-07-14-0672-PDN

Powell, G. K., and Morris, R. O. (1986). Nucleotide sequence and expression of a Pseudomonas savastanoi cytokinin biosynthetic gene: homology with Agrobacterium tumefaciens tmr and tzs loci. Nucleic Acids Res. 14, 2555-2565. doi: 10.1093/nar/14.6.2555

Prada-Ramirez, H. A., Perez-Mendoza, D., Felipe, A., Martinez-Granero, F., Rivilla, R., Sanjuan, J., et al. (2016). AmrZ regulates cellulose production in Pseudomonas syringae pv. tomato DC3000. Mol. Microbiol. 99, 960-977. doi: $10.1111 / \mathrm{mmi} .13278$

Pulawska, J. (2010). Crown gall of stone fruits and nuts, economic significance and diversity of its causal agents: tumorigenic Agrobacterium spp. J. Plant Pathol. 92, S1.87-S1.98. doi: 10.4454/jpp.v92i1sup.2510

Putnam, M. L., Curtis, M., Serdani, M., and Palmateer, A. J. (2010). Pseudomonas savastanoi found in association with stem galls on Mandevilla. Phytopathology 100:s104.

Quesada, J. M., García, A., Bertolini, E., López, M. M., and Penyalver, R. (2007). Recovery of Pseudomonas savastanoi pv. savastanoi from symptomless shoots of naturally infected olive trees. Int. Microbiol. 10, 77-84. doi: 10.2436/20.1501. 01.11

Ralph, J., Lundquist, K., Brunow, G., Lu, F., Kim, H., Schatz, P. F., et al. (2004). Lignins: natural polymers from oxidative coupling of 4-hydroxyphenylpropanoids. Phytochem. Rev. 3, 29-60. doi: 10.1023/B:PHYT.0000047809. 65444.a4

Ramos, C., Matas, I. M., Bardaji, L., Aragón, I. M., and Murillo, J. (2012). Pseudomonas savastanoi pv. savastanoi: some like it knot. Mol. Plant Pathol. 13, 998-1009. doi: 10.1111/j.1364-3703.2012.00816.x

Rodríguez-Moreno, L., Barcelo-Munoz, A., and Ramos, C. (2008). In vitro analysis of the interaction of Pseudomonas savastanoi pvs. savastanoi and nerii with micropropagated olive plants. Phytopathology 98, 815-822. doi: 10.1094/ PHYTO-98-7-0815

Rodríguez-Moreno, L., Jimenez, A. J., and Ramos, C. (2009). Endopathogenic lifestyle of Pseudomonas savastanoi pv. savastanoi in olive knots. Microb. Biotechnol. 2, 476-488. doi: 10.1111/j.1751-7915.2009.00101.x
Rodríguez-Palenzuela, P., Matas, I. M., Murillo, J., Lopez-Solanilla, E., Bardaji, L., Pérez-Martínez, I., et al. (2010). Annotation and overview of the Pseudomonas savastanoi pv. savastanoi NCPPB 3335 draft genome reveals the virulence gene complement of a tumour-inducing pathogen of woody hosts. Environ. Microbiol. 12, 1604-1620. doi: 10.1111/j.1462-2920.2010.02207.x

Rojas, A. M., de los Rios, J. E., Fischer-Le Saux, M., Jimenez, P., Reche, P., Bonneau, S., et al. (2004). Erwinia toletana sp. nov., associated with Pseudomonas savastanoi-induced tree knots. Int. J. Syst. Evol. Microbiol. 54, 2217-2222. doi: 10.1099/ijs.0.02924-0

Romling, U., Gomelsky, M., and Galperin, M. Y. (2005). C-di-GMP: the dawning of a novel bacterial signalling system. Mol. Microbiol. 57, 629-639. doi: 10.1111/ j.1365-2958.2005.04697.x

Ryan, R. P. (2013). Cyclic di-GMP signalling and the regulation of bacterial virulence. Microbiology 159, 1286-1297. doi: 10.1099/mic.0.068189-0

Ryan, R. P., Lucey, J., O’donovan, K., Mccarthy, Y., Yang, L., Tolker-Nielsen, T., et al. (2009). HD-GYP domain proteins regulate biofilm formation and virulence in Pseudomonas aeruginosa. Environ. Microbiol. 11, 1126-1136. doi: $10.1111 / j .1462-2920.2008 .01842 . x$

Sakakibara, H. (2006). Cytokinins: activity, biosynthesis, and translocation. Annu. Rev. Plant Biol. 57, 431-449. doi: 10.1146/annurev.arplant.57.032905.105231

Santner, A., and Estelle, M. (2009). Recent advances and emerging trends in plant hormone signalling. Nature 459, 1071-1078. doi: 10.1038/nature08122

Schulmeyer, K. H., and Yahr, T. L. (2017). Post-transcriptional regulation of type III secretion in plant and animal pathogens. Curr. Opin. Microbiol. 36, 30-36. doi: 10.1016/j.mib.2017.01.009

Sisto, A., Cipriani, M. G., and Morea, M. (2004). Knot formation caused by Pseudomonas syringae subsp. savastanoi on olive plants is hrp-dependent. Phytopathology 94, 484-489. doi: 10.1094/PHYTO.2004.94.5.484

Sisto, A., Morea, M., Zaccaro, F., Palumbo, G., and Iacobellis, N. S. (1999). Isolation and characterization of Pseudomonas syringae subsp. savastanoi mutants defective in hypersensitive response elicitation and pathogenicity. J. Phytopathol. 147, 321-330. doi: 10.1046/j.1439-0434.1999.00398.x

Smidt, M., and Kosuge, T. (1978). The role of indole-3-acetic acid accumulation by alpha methyl tryptophan-resistant mutants of Pseudomonas savastanoi in gall formation on oleanders. Physiol. Plant Pathol. 13, 203-213. doi: 10.1016/00484059(78)90035-8

Soby, S., Kirkpatrick, B., and Kosuge, T. (1991). Chemotaxis of Pseudomonas syringae subsp. savastanoi virulence mutants. Appl. Environ. Microbiol. 57, 2918-2920.

Sondermann, H., Shikuma, N. J., and Yildiz, F. H. (2012). You've come a long way: c-di-GMP signaling. Curr. Opin. Microbiol. 15, 140-146. doi: 10.1016/j. mib.2011.12.008

Spaepen, S., and Vanderleyden, J. (2011). Auxin and plant-microbe interactions. Cold Spring Harb. Perspect. Biol. 3:a001438. doi: 10.1101/cshperspect.a001438

Spaepen, S., Vanderleyden, J., and Remans, R. (2007). Indole-3-acetic acid in microbial and microorganism-plant signaling. FEMS Microbiol. Rev. 31, 425448. doi: 10.1111/j.1574-6976.2007.00072.x

Subramoni, S., and Venturi, V. (2009). LuxR-family 'solos': bachelor sensors/regulators of signalling molecules. Microbiology 155, 1377-1385. doi: 10.1099/mic.0.026849-0

Sultan, S. Z., Pitzer, J. E., Boquoi, T., Hobbs, G., Miller, M. R., and Motaleb, M. A. (2011). Analysis of the HD-GYP domain cyclic dimeric GMP phosphodiesterase reveals a role in motility and the enzootic life cycle of Borrelia burgdorferi. Infect. Immun. 79, 3273-3283. doi: 10.1128/IAI. 05153-11

Surico, G. (1977). Histological observations on tumours of olive knot. Phytopathol. Mediterr. 16, 106-125.

Surico, G., Iacobellis, N. S., and Sisto, A. (1985). Studies on the role of indole-3acetic acid and cytokinins in the formation of knots on olive and oleander plants by Pseudomonas syringae pv. savastanoi. Physiol. Plant Pathol. 26, 309-320. doi: 10.1016/0048-4059(85)90006-2

Tamayo, R., Pratt, J. T., and Camilli, A. (2007). Roles of cyclic diguanylate in the regulation of bacterial pathogenesis. Annu. Rev. Microbiol. 61, 131-148. doi: 10.1146/annurev.micro.61.080706.093426

Tegli, S., Gori, A., Cerboneschi, M., Cipriani, M. G., and Sisto, A. (2011). Type three secretion system in Pseudomonas savastanoi pathovars: Does timing matter? Genes 2, 957-979. doi: 10.3390/genes2040957 
Temsah, M., Hanna, L., and Saad, A. T. (2007a). Anatomical observations of Pseudomonas savastanoi on Rhamnus alaternus. For. Pathol. 37, 64-72. doi: 10.1111/j.1439-0329.2007.00483.x

Temsah, M., Hanna, L., and Saad, A. T. (2007b). Histology of pathogenesis of Pseudomonas savastanoi on Myrtus communis. J. Plant Pathol. 89, 241-249.

Temsah, M., Hanna, L., and Saad, A. T. (2008). Anatomical pathogenesis of Pseudomonas savastanoi on olive and genesis of knots. J. Plant Pathol. 90, 225-232.

Temsah, M., Hanna, L., and Saad, A. T. (2010). Histological pathogenesis of Pseudomonas savastanoi on Nerium oleander. J. Plant Pathol. 92, 407-413.

Thomashow, L. S., Reeves, S., and Thomashow, M. F. (1984). Crown gall oncogenesis: evidence that a T-DNA gene from the Agrobacterium Ti plasmid pTiA6 encodes an enzyme that catalyzes synthesis of indoleacetic acid. Proc. Natl. Acad. Sci. U.S.A. 81, 5071-5075. doi: 10.1073/pnas.81.16.5071

Ullrich, C. I., and Aloni, R. (2000). Vascularization is a general requirement for growth of plant and animal tumours. J. Exp. Bot. 51, 1951-1960. doi: 10.1093/ jexbot/51.353.1951

Valentini, M., and Filloux, A. (2016). Biofilms and cyclic di-GMP (c-di-GMP) signaling: lessons from Pseudomonas aeruginosa and other bacteria. J. Biol. Chem. 291, 12547-12555. doi: 10.1074/jbc.R115.711507

Von Bodman, S. B., Bauer, W. D., and Coplin, D. L. (2003). Quorum sensing in plant-pathogenic bacteria. Annu. Rev. Phytopathol. 41, 455-482. doi: 10.1146/ annurev.phyto.41.052002.095652

Waite, C., Schumacher, J., Jovanovic, M., Bennett, M., and Buck, M. (2017). Negative autogenous control of the master type III secretion system regulator HrpL in Pseudomonas syringae. mBio 8:e2273-16. doi: 10.1128/mBio. 02273-16

Wilson, E., and Magie, A. (1964). Systemic invasion of the host plant by the tumorinducing bacterium, Pseudomonas savastanoi. Phytopathology 54, 577-579.

Wilson, E. E. (1965). Pathological histogenesis in oleander tumors induced by Pseudomonas savastanoi. Phytopathology 55, 1244-1249.

Xiao, Y., Heu, S., Yi, J., Lu, Y., and Hutcheson, S. W. (1994). Identification of a putative alternate sigma factor and characterization of a multicomponent regulatory cascade controlling the expression of Pseudomonas syringae pv. syringae Pss61 hrp and hrmA genes. J. Bacteriol. 176, 1025-1036. doi: 10.1128/ jb.176.4.1025-1036.1994

Xiao, Y., and Hutcheson, S. W. (1994). A single promoter sequence recognized by a newly identified alternate sigma factor directs expression of pathogenicity and host range determinants in Pseudomonas syringae. J. Bacteriol. 176, 3089-3091. doi: 10.1128/jb.176.10.3089-3091.1994

Yang, F., Tian, F., Sun, L., Chen, H., Wu, M., Yang, C. H., et al. (2012). A novel twocomponent system PdeK/PdeR regulates c-di-GMP turnover and virulence of Xanthomonas oryzae pv. oryzae. Mol. Plant Microbe Interact. 25, 1361-1369. doi: 10.1094/MPMI-01-12-0014-R

Yang, S., Zhang, Q., Guo, J., Charkowski, A. O., Glick, B. R., Ibekwe, A. M., et al. (2007). Global effect of indole-3-acetic acid biosynthesis on multiple virulence factors of Erwinia chrysanthemi 3937. Appl. Environ. Microbiol. 73, 1079-1088. doi: 10.1128/AEM.01770-06

Yi, X., Yamazaki, A., Biddle, E., Zeng, Q., and Yang, C. H. (2010). Genetic analysis of two phosphodiesterases reveals cyclic diguanylate regulation of virulence factors in Dickeya dadantii. Mol. Microbiol. 77, 787-800. doi: 10.1111/j.13652958.2010.07246.x

Yuan, Z.-C., Haudecoeur, E., Faure, D., Kerr, K. F., and Nester, E. W. (2008). Comparative transcriptome analysis of Agrobacterium tumefaciens in response to plant signal salicylic acid, indole-3-acetic acid and $\gamma$-amino butyric acid reveals signalling cross-talk and Agrobacterium-plant co-evolution. Cell. Microbiol. 10, 2339-2354. doi: 10.1111/j.1462-5822.2008.01215.x

Conflict of Interest Statement: The authors declare that the research was conducted in the absence of any commercial or financial relationships that could be construed as a potential conflict of interest.

Copyright (C) 2017 Caballo-Ponce, Murillo, Martínez-Gil, Moreno-Pérez, Pintado and Ramos. This is an open-access article distributed under the terms of the Creative Commons Attribution License (CC BY). The use, distribution or reproduction in other forums is permitted, provided the original author(s) or licensor are credited and that the original publication in this journal is cited, in accordance with accepted academic practice. No use, distribution or reproduction is permitted which does not comply with these terms. 